Nueva España, Filipinas, consolidación, fortalecimiento, autonomía política de los gobernadores filipinos

\title{
INTENTOS DE FORTALECIMIENTO ESPAÑOL ALLENDE FILIPINAS: MOLUCO, MATHEO E ISLA DEL NORTE, 1605-1653
}

\author{
OSTWALD SALES-COLÍN KORTAJARENA \\ Universidad Autónoma Metropolitana
}

\section{Introducción}

El ánimo español expansionista que recorría el sureste asiático desde la segunda mitad del siglo XVI tuvo eco durante la primera mitad del siglo XVII, una época decisiva en el archipiélago filipino conocida con el calificativo de "consolidación de la presencia hispana", ${ }^{1}$ la cual, en apariencia, puede parecer reveladora debido a que se asiste a un objeto de estudio que, a pesar de contar con importantes contribuciones, está muy lejos de considerarse agotado o suficientemente analizado. De todo ello, los archivos albergan una enorme masa documental que arroja información sobre las empresas, los asentamientos españoles allende Filipinas, las realidades impuestas por esa avanzada y la imagen que los miembros de la élite gobernante tenían de aquellos territorios.

Las fuentes en las que se basa esta investigación se encuentran en el Archivo General de Indias, Archivo General de Simancas, Archivo Histórico Nacional de Toledo, Archivo del Museo Naval de Madrid, Biblioteca Nacional de Madrid,

Este artículo fue recibido por la dirección de la revista el 5 de julio de 2013 y aceptado para su publicación el 23 de agosto de 2013.

${ }^{1}$ María de Lourdes Díaz-Trechuelo, "Las Filipinas, en su aislamiento, bajo el continuo acoso”, en Historia general de España y América. América en el siglo XVII. Evolución de los reinos hispánicos, tomo IX-2, Madrid, Rialp, 1984, pp. 129-152; Antonio Molina, Historia general de Filipinas, Madrid, Ediciones de Cultura Hispánica-Instituto de Cooperación Iberoamericana, 1984, vol. 2, pp. 97-113; Inmaculada Alva Rodríguez, "La centuria desconocida: el siglo XvII", en L. Cabrero (coord.), Historia general de Filipinas, Madrid, Ediciones de Cultura Hispánica, 2000, pp. 207-248. 
Servicio Histórico Militar, Archivo General de la Nación y Archivo Histórico del Instituto Nacional de Antropología e Historia. Refieren un momento de la historia de Filipinas en que existe la idea de que la monarquía aún no ha terminado su avanzada en el Moluco y las riberas del mar de China, marcada bajo el prisma de la reputación, más que con la viva fuerza de las armas. Desde $1574^{2}$ aquel archipiélago pasaba a depender oficialmente de la Nueva España y, al igual que los territorios americanos, sirvió como cabeza de puente para implantar el poder en lugares lejanos de la metrópoli. Tal fenómeno se logró gracias a la enrevesada logística en Insulindia, manifiesta en las decisiones de los gobernadores generales filipinos interesados en expandir los territorios bajo jurisdicción española, que no tomaban parecer al virrey mexicano argumentando lejanía, atraso y desconocimiento de las reales órdenes.

En esta primera mitad del siglo XVII se desarrollaron una serie de programas para ocupar el Moluco ${ }^{3}$ (1606), Matheo ${ }^{4}$ (16211625) y la isla del Norte $^{5}$ (1626). Se evidencia el radio de expansión de más amplio alcance sobre Asia oriental y las riberas del mar de China. En conjunto, constituyeron un intento significativo, como parte de los proyectos, donde se observa el afianza-

${ }^{2}$ Antonio García-Abásolo, "La expansión mexicana hacia el Pacífico: la primera colonización de Filipinas. 1570-1580”, Historia Mexicana, vol. XXXII (1), núm. 125, julio-septiembre de 1982, pp. 55-88.

${ }^{3}$ La isla de Ternate era llamada Maluco, Moluco o presidio del Moluco por formar parte de las islas de la Especiería, entre las que destacaban Halmahera, Amboine, Tidore, Buru y Ternate, que forman el archipiélago de las Molucas que abraza las islas de Tidore, Policaballo, Montiel, Maquien, Bachán y Batachina.

${ }^{4} \mathrm{La}$ actual isla de Sulawesi o Célebes era conocida como Macasar. No obstante, Macasar no sólo era uno de los reinos del lugar, sino el más importante. Los restantes fueron Boni, Bool, Canripa y Monados. Las fuentes de la época son precisas. Para referirse a la isla de los tentáculos aparece escrito recurrentemente el nombre de Matheo; con ello se establecían claramente dos acepciones: Matheo es toda la isla y Macasar sólo es uno de los reinos de Matheo. No hay que confundir ambos términos porque en la documentación se insiste en que el reino de Macasar es el más poderoso de Matheo.

${ }^{5} \mathrm{Se}$ le conocía como isla Hermosa. De acuerdo con los informes que he consultado aparece de forma reiterada el epíteto gran isla del Norte. La presencia hispana marcó una identidad propia ya que el nombre de isla Hermosa o Formosa era de cuño lusitano. Se intentó llevar a cabo una diferenciación porque los portugueses tenían una firme posición en el comercio chino con su asentamiento en Macao que obstaculizaba los esfuerzos españoles por establecer el trato sin esos intermediarios. A lo largo de esta comunicación se usa indistintamente isla del Norte, Formosa o isla Hermosa, pues las dos últimas ganaron popularidad entre los portulanos europeos y las informaciones españolas. Actualmente es la isla de Taiwan. 
miento de la presencia española en Filipinas, que avanzaba hacia a las regiones más meridionales del archipiélago, como Mindanao; además, se percibe un estado de "continuo acoso" con la presencia de dos guerras endémicas: la hispano-holandesa, en el norte, ${ }^{6}$ y la hispano-mahometana, en el sur. ${ }^{7}$

El reino asiático ${ }^{8}$ no experimentaba precisamente momentos de bonanza: levantamientos sangleyes en 1603 y 1639 ; revueltas indígenas como reacción contra la inconformidad en las formas de explotación y onerosa carga de trabajo impuestas por los agustinos calzados hacia 1650; ${ }^{9}$ endurecimiento de las posiciones políticas entre el gobernador general y la Real Audiencia de Manila entre 1600-1639; pérdida de barcos, naufragios e incomunicaciones navales como las de los años 1646-1648; incursiones para realizar una conquista interna contra indígenas zambales e igorotes; escasez de soldados; mínima liquidez de la hacienda insular; ${ }^{10}$ hasta la idea de Sebastián Hurtado de Corcuera apoyada en anular el situado novohispano para que las islas vivieran de los recursos de la tierra filipina a fin de evitar la onerosa carga económica para el virreinato mexicano. ${ }^{11}$

${ }^{6}$ Filipinas contra holandeses, Manila, 18 junio de 1648, Biblioteca Nacional de Madrid (BNM), Sala Cervantes, 2349-II, tomo vII.

${ }^{7}$ Memorial sobre los indios de Mindanao, en Archivo Histórico Nacional, Toledo (AHN), Nobleza, Manila, 8 de septiembre de 1655, legajo 387, doc. 20.

${ }^{8}$ Cuando Filipinas se constituyó en una provincia más del virreinato de la Nueva España recibió el sobrenombre del reino de la Nueva Castilla, aunque en realidad se le conocía como poniente, de ahí que se haga referencia al archipiélago como el reino asiático.

${ }^{9}$ Información hecha por el juez provisor y vicario general de este arzobispado de los tratos y contratos que los religiosos de San Agustín de las islas Filipinas tienen con los naturales de los partidos y doctrinas que administran, Manila, 4 de agosto de 1650, Archivo General de Indias, Sevilla (AGI), Filipinas 9, legajo 13, exp. 4.

${ }^{10}$ Alva Rodríguez, "La centuria desconocida", op. cit., pp. 149-176. Díaz-Trechuelo, "Las Filipinas, en su aislamiento", op. cit., pp. 129-152.

${ }^{11}$ Carta de Sebastián Hurtado de Corcuera sobre ayuda de sangleyes para fortificación, Manila, 30 de junio de 1636, AGI, Filipinas 8, legajo 54, exp. 1. Carta de Sebastián Hurtado de Corcuera sobre licencias de sangleyes, ibid., legajo 55, exp. 1. Carta de Sebastián Hurtado de Corcuera sobre negros libres llevados a isleta, ibid., legajo 58, exp. 1. Carta de Sebastián Hurtado de Corcuera sobre asuntos de gobierno, Manila, 11 de julio de 1636, AgI, Filipinas 8, legajo 76, exp. 1. Luis Alonso Alvarez habla de la economía interna filipina como un mecanismo del funcionamiento de la economía externa que garantiza la lealtad de las islas a la Corona; véase Alonso Álvarez, El costo del imperio asiático. La formación colonial de las islas Filipinas bajo dominio español, 1565-1800, México-Coruña, Instituto Mora-Universidade da Coruña, 2009, p. 137. 
Todos estos procesos generaron cuantiosos documentos donde se describen las avanzadas, sus características y las formas como se llevarían a cabo. Los que se presentan aquí están imbricados con esos escarceos; en algunos casos están muy lejos de ofrecer una imagen idílica al encontrarse en ellos voces desalentadoras como las de Rodrigo de Vivero, Juan Cerezo de Salamanca, Sebastián Hurtado de Corcuera y el Consejo de Indias. Antes de seguir, es obligatorio precisar los conceptos de "consolidación" y fortalecimiento de la presencia española.

En la historiografía, el calificativo de "consolidación de la presencia hispana" en las Filipinas de la primera mitad del siglo XVII se ha convertido en un tópico que clasifica una época de cambio frente al siglo anterior; un periodo decisivo en la expansión hacia las islas del Pacífico e Insulindia que manifiesta uno de los rasgos fundamentales de continuo interés activo en función de ampliar la jurisdicción de la monarquía allende el archipiélago. Se entiende por interés activo la necesidad de la logística interna que "trataba de afirmar la soberanía hispana"; ${ }^{12}$ es decir, dar firmeza y solidez a la autoridad del rey "al cobijo de una administración central y estable". ${ }^{13}$ Si se utiliza el concepto consolidación como una hipótesis de trabajo que se apoya en hiperbolizar la cristianización, ${ }^{14}$ sobrevalorar el complejo arquitectónico ${ }^{15} \mathrm{y}$ abusar del comercio transpacífico, pretendiendo que esos intercambios son determinantes

${ }^{12}$ Díaz-Trechuelo, "Las Filipinas, en su aislamiento", op. cit., p. 129.

${ }^{13}$ Molina, Historia general de Filipinas, op. cit., p. 97.

${ }^{14}$ María de Lourdes Díaz-Trechuelo, "Bibliografía española sobre Filipinas en el siglo xx”, en F. Solano, F. Rodao y L. E. Togores (eds.), Extremo oriente ibérico. Investigaciones históricas: metodología y estado de la cuestión, Madrid, Agencia de Cooperación Internacional-Consejo Superior de Investigaciones Científicas, 1989, pp. 343-382; Antonio García-Abásolo, "Investigaciones sobre Filipinas en Andalucía”, Revista de Indias, vol. XLIX, núm. 187, 1989, pp. 767-778; Manuel González Pola, "Dominicos en extremo oriente. Bibliografía general sobre su actividad misionera", en Solano, Rodao y Togores (eds.), El extremo oriente ibérico, op. cit., pp. 277-295; Lucio Gutiérrez, Historia de la Iglesia en Filipinas. 1565-1900, Madrid, Mapfre, 1992; Ana María Prieto Lucena, "El Pacífico en las revistas del CSIC", Revista de Indias, vol. XLIX, núm. 187, 1989, pp. 829-844; Leandro Tormo Sanz, "Bibliografía sobre la historia de la Iglesia en el extremo oriente relacionada con España”, en Solano, Rodao y Togores (eds.), El extremo oriente ibérico, op. cit., pp. 391-413.

${ }^{15}$ Inmaculada Alva Rodríguez, "Urbanismo municipal en Manila (siglos XVI-XVII)", en A. García-Abásolo (coord.), España y el Pacífico, Córdoba, Universidad de CórdobaInstituto de Cooperación Internacional, 1997, pp. 157-165; Archivo General de Indias, Paisajes urbanos de América y Filipinas, Sevilla, Ministerio de Educación, Cultura y 
entre ambas costas del océano Pacífico, ${ }^{16}$ entonces, fuera de toda duda, puede hablarse de consolidación, siempre que tales características sean evidentes, es decir, constatables más allá de "la gran Manila", ${ }^{17}$ de las áreas circunvecinas y no sólo en las principales ciudades con mayor concentración de habitantes españoles y novohispanos. Evidentemente, "Filipinas no es sólo Manila”, ${ }^{18}$ y es absolutamente necesario estudiar "más allá de la muralla". 19

Que naturalmente todavía no se trate de una consolidación propiamente dicha en el sentido geográfico, que abarque la totalidad del archipiélago, es porque no se logran controlar en su conjunto otros asentamientos importantes en Bisayas, tales como Bohol, Campot en Cebú, Negros, Calamianaes y Cuyo, la gran isla de Mindanao, la pequeña Joló, además de la conquista interna inacabada de Luzón en las regiones de Zambales, Ituy, los montes Igorrotes, así como de los indígenas llamados aetas, nómadas que mantuvieron escasos contactos con los europeos. Incluso en la segunda mitad del siglo XVII se dejarán de lado los ideales expansivos con objeto de realizar una internalización en el propio archipiélago.

En los escritos de la época no aparece la palabra consolidación. Ahora bien, existen numerosos testimonios que ilustran cómo las fuentes no escatiman el uso de la expresión fortalecimiento del asiento español, al verla como algo razonable, sin que

Deporte, 2000; María de Lourdes Díaz-Trechuelo, Arquitectura española en Filipinas, 1565-1800, Sevilla, Escuela de Estudios Hispanoamericanos, 1959.

${ }^{16}$ María García, "La batalla de la seda", en A. Tortolero (coord.), Estudios históricos, México, Universidad Autónoma Metropolitana, 1993, pp. 39-67; María García, "El comercio Acapulco-Manila: un intento de estado de la cuestión", en C. Yuste (coord.), Comercio marítimo colonial. Nuevas interpretaciones y últimas fuentes, México, Instituto Nacional de Antropología e Historia, 1997, pp. 165-180; Carmen Yuste López, El comercio de la Nueva España con Filipinas, 1590-1785, México, Instituto Nacional de Antropología e Historia, 1984, y Emporios transpacificos. Comerciantes mexicanos en Manila. 1710-1815, México, Instituto de Investigaciones Históricas de la Universidad Nacional Autónoma de México, 2007.

${ }^{17}$ Antonio Aguilera Rojas, Manila, 1571-1898. Occidente en Oriente, Madrid, Universidad de Alcalá-Instituto Español de Arquitectura-Agencia Española de Cooperación Internacional-Ministerio de Asuntos Exteriores-Ministerio de Fomento-Centro de Estudios y Experimentación de Obras Públicas-Centro de Estudios Históricos de Obras Públicas y Urbanismo, 1988, p. 82.

${ }^{18}$ Ibid., p. 130.

${ }^{19}$ Ibid., p. 76. 
resulte pretenciosa. Puntualiza cómo los españoles se arrogaban derechos en las posesiones hispano-filipinas ya sometidas, como en Luzón y Bisayas, además de avanzar a las islas del Pacífico asiático y robustecer su presencia en la región al ejercer un irredentismo sui géneris sobre nuevos territorios que consideraban parte de la monarquía. En todo caso, la idea principal es ver el fortalecimiento como un grupo de denodados planes y proyectos concentrados en la consecución de una política expansionista, que buscaba descubrir las características económicas de las islas más importantes del archipiélago insulindio, lo cual está asistido por el afianzamiento de las posesiones hispano-filipinas ya dominadas que continuarán, bajo jurisdicción española, durante el resto de la presencia de la monarquía en Asia. Entonces, se asiste a planes, proyectos, establecimientos reales y presencia hispana, un intento de fortalecimiento allende Filipinas, respaldado en confirmar y hacer vigoroso el asiento permanente de gente, al emular al fundado en Manila.

En ese sentido, se puede hablar de intentos de fortalecimiento, actividades asociadas a marinos, soldados, mercaderes, misioneros, diplomáticos, oficios de baja estofa. Todos viajaban a "naciones" y lugares extraños con diferentes lenguas, costumbres, creencias y formas de organización, con la pretensión de implantar el poder en aquellos lugares que exploraban, recorrían, intentaban dominar y, en dado caso, abandonaban, con la reserva de haberlos conocido de forma aproximada. ${ }^{20}$

Se estableció claramente la búsqueda de lo que podría redundar en beneficio de las arcas del rey, pero al tratarse de un fenómeno de establecimiento del poder ordenado y programado, el esfuerzo organizativo y administrativo se efectuaba en su mayor parte en Manila, incorporándose a ese alambicado ordenamiento mundial de los Austrias. Además, la importancia de las Bisayas plasma los intereses de avanzada sobre las islas del Pacífico. Igualmente, no hay que exagerar la injerencia metropolitana en asuntos filipinos, aunque sí se presionaba al virrey de Nueva España para que lograra paliarlos, atenuarlos perentoriamente $y$, si era posible, resolverlos. La implantación

${ }^{20}$ Paloma García Picazo, ¿Qué es esa cosa llamada "relaciones internacionales”? Tres lecciones de autodeterminación y algunas consideraciones indeterministas, MadridBarcelona, Marcial Pons, 2000, p. 136. 
del poder español allende Filipinas, y su fortalecimiento, sí era una prioridad, y las esperanzas de lograrlo, muy grandes.

La importancia del fortalecimiento radica en servir de refuerzo para comparar y cotejar las opiniones del reducido grupo de especialistas, además de proponer hipótesis de trabajo. Por ejemplo, puede plantearse como un fenómeno opuesto al que experimenta España en Europa frente a la pérdida de la hegemonía política, sumergida en la guerra de Treinta Años y la crisis económica del siglo XVII en consonancia con la amplia autonomía económica de los reinos americanos. ${ }^{21}$ Mientras, en Filipinas, continúan las empresas de avance hacia las islas del Pacífico, tal como lo plantea Alva Rodríguez. ${ }^{22}$

El contraste es evidente, sin que se centre exclusivamente en Manila y las áreas vecinas a la capital. Supuso un esfuerzo para evitar que el archipiélago continuara dependiendo del comercio transpacífico mediante los intentos por establecer una ruta contraria por el cabo de Buena Esperanza, al destacar, desde Ternate ${ }^{23}$ un galeón hacia España, en coincidencia con el criterio activo de la adquisición de posesiones con un carácter predominantemente político-comercial. Se sugería y fomentaba, de forma embrionaria, una autonomía económica insular centrada en los recursos naturales in situ, dejando del lado la visión tradicional de una posesión deficitaria. La insistencia se centraba en los intrépidos intentos por desaparecer la presencia de los comerciantes mexicanos en Manila. ${ }^{24}$

${ }^{21}$ Véase, de Geoffrey Parker: La guerra de los Treinta Años, Barcelona, Crítica, 1988, y España y la rebelión de Flandes, Madrid, Nerea, 1989; y de Pedro Pérez Herrero: Plata y libranzas. La articulación económica del México borbónico, México, El Colegio de México, 1988; Comercio y mercados en América latina colonial, Madrid, Mapfre, 1992, pp. 155-163; y América Latina y el colonialismo europeo (siglos XV-XVIII), Madrid, Síntesis, 1992, pp. 101-116, y de Ruggero Romamo, Coyunturas opuestas: la crisis del siglo XVII en Europa e Hispanoamérica, México, El Colegio de México-Fondo de Cultura Económica, 1993.

${ }^{22}$ Alva Rodríguez, "La centuria desconocida", op. cit., p. 220.

${ }^{23}$ Noticias de Filipinas, jornadas hechas en 1578 y 1579 a Borneo, Mindanao y Joló, testimonios y diligencias hechas por mandato de don Francisco de Sande, gobernador y capitán general de Filipinas, Manila, 30 de mayo de 1579, Archivo General de Simancas, Valladolid (AGs), Guerra Antigua, legajo 90, exp. 63.

${ }^{24} \mathrm{Al}$ respecto existe la contribución de Carmen Yuste López. Y aunque se centra en el siglo XVIII, los planteamientos relativos a los siglos XVI y XVII pueden considerarse un intento razonado y detallado de los primeros años de la presencia novohispana en el sureste asiático. Yuste López, Emporios transpacíficos, op. cit., pp. 75-148. 
Desde la década de 1580,25 los objetivos españoles estuvieron encaminados a la creación o ampliación, de acuerdo con Luis Alonso Álvarez, "de un imperio asiático, paralelo al americano", ${ }^{26}$ que procura expandirse, imponerse en la región y conservar su posición en el marco europeo de potencias. La nueva empresa comienza, en 1578, con las expediciones a Borneo encabezadas por Francisco de Sande (1576-1580), y Gómez Pérez Dasmariñas cuando partía a la conquista de Ternate hacia 1593. Durante el siglo xvII, los Estados modernos, entre ellos España, buscan la expansión y el afianzamiento mediante una amplia red de funcionarios que, al representar a la burocracia estatal, legitiman todo tipo de actuaciones con una clara orientación al orden, la administración y la planificación, incluidas las más incontrolables e irracionales. ${ }^{27}$ Aquí las razones de ampliar su jurisdicción a las islas comarcanas, manteniéndolas sufragáneas de la Corona.

Al mismo tiempo, se constata aún más el argumento de Florentino Rodao, ${ }^{28}$ para quien el archipiélago se encontraba comunicado con sus islas hermanas y mantenía el nexo con el exterior a través del comercio realizado con Acapulco. Otra razón para incluirlo es que gracias a la pervivencia de la navegación Acapulco-Manila pudieron llegar recursos económicos, materiales y humanos desde Nueva España, ${ }^{29}$ para empresas contra las que existían voces severas e implacables que no estaban de acuerdo en continuar con una avanzada.

En conjunto, en este trabajo se hace referencia a las dificultades para asentarse en la región; se muestran las ventajas de

${ }^{25}$ En este caso, el nuevo proyecto no finaliza; habrá de entenderse como el cierne de uno más amplio hasta la ocupación del Moluco, las esperanzas puestas en Matheo y el establecimiento español en Formosa; véase Alonso Álvarez, El costo del imperio asiático, op. cit., p. 31.

${ }^{26}$ Ibid., pp. 30-31.

${ }^{27}$ Ernest Hinrichs, Introducción a la historia de la edad moderna, Madrid, Akal, 2001, pp. 204-221.

${ }^{28}$ Florentino Rodao, Españoles en Siam (1540-1939). Una aportación al estudio de la presencia hispana en Asia, Madrid, Consejo Superior de Investigaciones Científicas, 1997, p. 42.

${ }_{29}$ Antonio García-Abásolo, "Formación de las Indias orientales españolas. Filipinas en el siglo XvI", en L. Cabrero (coord.), Historia general de Filipinas, Madrid, Ediciones de Cultura Hispánica, 2000, pp. 169-205. Ostwald Sales-Colín, "Las cargazones del galeón de la carrera de poniente: primera mitad del siglo XvII", Revista de Historia Económica, año XVIII, núm. 3, otoño-invierno de 2000, pp. 629-669. 
establecerse en ella, lo que en las apariencias fortalecería aún más la presencia hispana en Asia, y se detallan las ventajas militares, poblacionales, religiosas, económicas y geoestratégicas que se desprenderían para Filipinas. Es obvio que no se pueden comentar aquí todas ellas, por lo cual se ha hecho una selección de las que además de ser proyectos, representan un análisis de aquella situación. Mi trabajo aborda las diferentes opiniones y relaciones, entre la coexistencia razonable y comprensiva, de los puntos de vista que dieron las autoridades sobre los asentamientos españoles allende Filipinas y la imagen que los miembros de la élite gobernante tenían de aquellos territorios.

\section{Asentamientos españoles allende Filipinas}

Una primera intención por establecerse en los ricos mercados indonesios se barajó, hacia 1582, cuando el capitán Antonio de la Torre propuso conquistar la isla de Sumatra al calor del éxito español en Luzón, la cual se poblaría con gente originaria de Filipinas, India, Portugal, Malaca y Nueva España, y se convertiría en una extensión de la capital española en Asia al encontrarse en medio del comercio de los archipiélagos insulindios. ${ }^{30}$ No era más que la vocación ineludible de llegar a la Especiería, que a la postre trajo la obligación de establecerse en el Moluco, cuyo interés activo databa desde el gobierno de Francisco de Sande (1575-1580), quien subrayaba muy animado que la Especiería se encontraba fuera del Empeño, ${ }^{31} \mathrm{y}$ al evitar el contacto con el virreinato de la Nueva España se posibilitarían las condiciones para fletar a Sevilla barcos hinchados de drogas ${ }^{32}$ y bujerías. ${ }^{33}$

La isla de la Especiería más importante para los españoles era Ternate, que estaba en manos de los lusitanos tras su pérdida en 1579; durante enero de 1583, el virrey de Nueva España comunicaba a Felipe II lo relacionado con la capitulación de

${ }^{30}$ Apuntes y memoria dada al capitán Antonio de la Torre para el viaje que va a hacer a Filipinas y Malaca, Madrid, 31 de marzo de 1582, AGS, Guerra Antigua, legajo 137, exp. 14.

${ }^{31}$ Empeño del Moluco o Tratado de Zaragoza.

${ }^{32}$ Así se le conocía corrientemente a las especias.

${ }^{33}$ Noticias de Filipinas..., op. cit., exp. 55. 
aquella isla. ${ }^{34}$ Tenían el paso libre para asentarse en la isla del clavero y, en consecuencia, se reveló que el proyecto más realista para fundar un presidio se apoyaba en suministrar todos los recursos materiales y humanos desde Luzón y Bisayas, tomando en cuenta la cercanía entre ambas islas. Lamentablemente, el peligro en la futura ruta de navegación era manifiesto porque sólo podrían llegar embarcaciones de pequeño y mediano porte; en la práctica, así sucedió cuando, en 1606, Ternate fue conquistada por Pedro Bravo de Acuña (1602-1606), ${ }^{35}$ de tal manera que el socorro del Moluco era enviado en galeras, pataches o fragatas. ${ }^{36}$ También se planteaba la cercanía al mar Banda y mar de la Sonda, donde la presencia holandesa era recurrente dada la constante entrada y salida de sus factorías indonesias, y es que en el transcurso de esta época llegaban refuerzos desde Provincias Unidas del Norte, barcos cargados con piedra, cal y canto para construir fortalezas como en Tidore. ${ }^{37}$

La presencia española en Insulindia empezaba a fortalecerse; en especial, era una ampliación del poder que se reconocía más allá de las islas de poniente, ${ }^{38}$ aunque sólo habían ocupado Calomata, en el norte, mientras los holandeses recobraron sus posesiones entre 1607 y 1608 con los enclaves de Talangame y el Malayo, en el sur. ${ }^{39}$ Ya en Calomata, Pedro Bravo de Acuña nombró a Juan Martínez de Esquivel como gobernador interino, al mando de 600 hombres, encargado de repeler los acechos holandeses y malayo-mahometanos, levantar la bandera española en nombre de Felipe III, y formalizar diferentes cláusulas con el rey de Ternate en aras de lograr un asentamiento estable con una progenie europea; mientras tanto, los nativos eran sometidos.

${ }^{34}$ Navegación de Filipinas a Nueva España, Manila, 10 de mayo de 1583, AGS, Guerra Antigua, legajo 141, exp. 2.

${ }^{35}$ Las fechas entre paréntesis corresponden al periodo de gobierno de cada capitán general en las islas.

${ }^{36}$ Carta de Hurtado de Mendoza a Pedro Bravo de Acuña sobre Ternate, Manila, 25 de marzo de 1603, AgI, Filipinas, legajo 7, exp. 6. Carta de Pedro Bravo de Acuña sobre el Moluco y Ternate, Manila, 10 de julio de 1603, AGI, Filipinas, legajo 7, exp. 6.

${ }^{37}$ Carta de Pedro Bravo de Acuña sobre la jornada del Moluco, Manila, 1 de julio de 1605, AGI, Filipinas, legajo 7, exp. 23.

${ }^{38}$ A Filipinas se le denomina en los documentos de la época islas de poniente.

${ }^{39}$ Juan Gil, Mitos y utopias del descubrimiento. 2. El Pacífico, Madrid, Alianza Universidad, 1989, p. 180. 
En el marco discursivo de la práctica enfrentaron una situación corriente, la flaqueza, irregularidad e insuficiencia del socorro moluqueño enviado desde Manila. Esta situación duradera no hace olvidar la subvención de dinero, soldados, municiones y víveres para sostener la presencia hispana, manifestándose, desde la segunda mitad del siglo XvI, una ancestral dependencia de México; así lo atestiguan Guido de Lavezaris en 1567 y 1568, Miguel López de Legazpi en 1572 y Francisco de Sande en $1576 .{ }^{40}$ Sin duda, en Insulindia se reproduce lo que Chaunu ha denominado la dependencia de Filipinas respecto a la Nueva España ${ }^{41}$ es decir, un reino encargado de satisfacer algunos de los emolumentos, obvenciones y pábulos de otro porque los gobernadores generales de occidente ${ }^{42}$ solicitaban diferentes mercancías y socorros de gente de mar y de guerra al virrey de México.

En Ternate sucedió un proceso similar, su socorro estaba subordinado al enviado desde Manila, constante cuando el galeón de Acapulco atracaba en los puertos de Manila o Cavite, pero mientras no había noticias de los barcos originarios de México, ya sea por retraso, zozobras, pérdidas, hundimientos o cambio de derrotero, se caracterizaba por su frugalidad, escasez, insuficiencia e insolvencia. Se consideró una estrategia tripartita ${ }^{43}$ en el ámbito genuino de las relaciones intercoloniales: ${ }^{44}$

\footnotetext{
${ }^{40}$ Noticias de las islas de poniente, 1542-1603, Madrid, 28 de noviembre de 1851, Servicio Histórico Militar, Madrid, Sección Asuntos Generales Luzón, núm. 6742, rollo 9.

${ }^{41}$ Pierre Chaunu, Las Filipinas y el Pacífico de los ibéricos, siglos XVI, XVII y XVIII, México, Instituto Mexicano de Comercio Exterior, 1976, p. 25.

${ }^{42}$ Occidente designaba las islas Filipinas desde una perspectiva cardinal, centrada en Nueva España; éstas se situaban al Oeste u Occidente como se reitera en la documentación consultada. No quiero que se confunda con la idea corriente que tácitamente ha aceptado que es equivalente a Europa y continuar engrosando las visiones eurocéntricas del establecimiento del poder en lugares lejanos de la metrópoli.

${ }^{43}$ Carta de Pedro Bravo de Acuña sobre la toma de Tidore por los holandeses, Manila, 6 de enero de 1606, AgI, Filipinas, legajo 7, exp. 29. Orden al virrey de México sobre artillería para Filipinas y Ternate, Manila, 8 de noviembre de 1608, AGI, Filipinas, legajo 329, exp. 29. Carta de Manuel Ribeiro a Fajardo de Tenza sobre Ternate, Manila, 10 de agosto de 1618, AGI, Filipinas, legajo 7, exp. 54.

${ }^{44}$ Este concepto debe manejarse con cuidado porque indica aspectos específicos de una tradición que continúa clasificando lo económico, lo político y lo religioso de las comunicaciones mexicano-filipinas sin considerar un contexto más amplio que refiera un intercambio de toda índole estructurado en ese fluir y que comprenda el resultado de una actividad social espontánea carente de fronteras, gobiernos y límites que separan
} 


\section{a) Desde Nueva España se enviaba el situado, ${ }^{45}$ una remesa de soldados y un grupo de efectos y víveres solicitados por el capitán general de Filipinas. Entre tales peticiones también se consideraba una ayuda dirigida especialmente para el Moluco. ${ }^{46}$}

arbitrariamente territorios y colectividades humanas. Sin duda, lo intercolonial implica riesgos. En cualquier caso, estoy consciente de que se sigue usando a falta de uno mejor. Leslie Bauzon, “Amplia perspectiva: relaciones intercoloniales mexicano-filipinas", en E. de la Torre Villar (comp.), La expansión hispanoamericana en Asia, siglos XVI-XVII, México, Fondo de Cultura Económica, 1980, pp. 77-85.

${ }^{45}$ La palabra situado, desde un punto de vista de la contabilidad mantenida entre Nueva España con su entorno americano y asiático, era una remisión de dinero más que transferencia desde las cajas mexicanas con un superávit a otra de déficit fiscal. En conjunto, se enviaban situados novohispanos compuestos de plata americana, naturalmente, de origen novohispano y peruano, a Cuba, la capitanía general de Yucatán, al norte chichimeca y a la capitanía general de Filipinas. Remisión, precisa la llegada de dinero que no se destinaba a la inversión para obtener una ganancia sino para gastarlo en las necesidades inmediatas consideradas como acuciantes. De acuerdo con el vocabulario de la época estudiada, y para ser más exactos, la remisión alude a diferentes partidas tales como situado, ayuda de Nueva España, gastos de factoría, guerra, misiones, sueldos y presidios. En suma, es el costo de la empresa filipina mantenida desde el virreinato mexicano, pues era gastada en bienes y servicios, guerras y misiones. La sección contaduría del AGI arroja información importante. La consulta que he realizado durante varios años en la sección Archivo Histórico de Hacienda del Archivo General de la Nación, México, en su parte relativa a efectos y víveres para poniente también aporta, al igual que el ramo General de Parte, informaciones complementarias y alternativas que pueden llevar a una revisión de todo el asunto, si es que se estudia a Filipinas en su justa dimensión, es decir, como una provincia más del virreinato mexicano, o como "colonia de la colonia". La discusión en torno del situado requiere aproximaciones todavía más puntuales. Alonso Álvarez, El costo del imperio asiático, op. cit., pp. 261-302; Chaunu, Las Filipinas y el Pacífico de los ibéricos, op. cit., pp. 26, 47 y 234. Ostwald Sales-Colín, "El movimiento portuario de Acapulco: un intento de aproximación (1626-1654)", Revista Complutense de Historia de América, núm. 22, 1996, pp. 97-119; y "Las cargazones del galeón de la carrera de poniente", op. cit., 2000, pp. 629-669.

${ }^{46}$ Certificación del socorro de Nueva España recibido en Manila, partida de reales y géneros de los años 1635-1640, Manila, 6 de junio de 1650, AGI, Filipinas, legajo 9, exp. 61. Géneros para Filipinas, México, 29 de marzo de 1628, Archivo General de la Nación, México (AGNM), Archivo Histórico de Hacienda (AHH), legajo 6, exp. 453. Géneros que se rematan para el despacho de la nao de Filipinas, México, 26 de marzo de 1628, ibid., exp. 430. Indices reales de títulos del despacho de la nao de Filipinas de 1634, México, 1634, ibid., exp. 206. Índices reales de títulos del despacho de la nao a Filipinas de 1636, México, 1636, ibid., exp. 201. Memorias de los géneros que se han de traer de Nueva España para Filipinas, México, 17 de septiembre de 1639, ibid., exp. 62. Índices reales de títulos del despacho de la nao a Filipinas de 1639, México, 1639, ibid., exp. 266. Índices reales de títulos del despacho de la nao a Filipinas de 1641, México, 1641, ibid., exp. 103. Géneros para la nao de Filipinas, 1 de marzo de 1645, AGNM, AHH, legajo 472, exp. 61. Memorial a nombre de las islas Filipinas contra un diputado sobre el comercio, México, 16 de enero de 1697, Archivo Histórico del Instituto Nacional 


\section{b) Del virreinato peruano se despachaba artillería. ${ }^{47}$ c) Luzón y Bisayas aportaban pertrechos, víveres y dinero.}

Los productos eran de Manila, Cebú y Panay. ${ }^{48}$ Pertrechos militares como arcabuces, mosquetes, balas, pólvora, salitre para fabricar pólvora, cuchillos y espadas; víveres, entre los que sobresalen arroz, gallinas, vino de tuba y nipa, ${ }^{49}$ galigala, ${ }^{50}$ carne de puerco y carabao; y dinero, cuya cantidad de plata variaba. Todos estos productos aportados por Luzón y Bisayas reflejan las coyunturas marítimas de la navegación transpacífica $y$, al mismo tiempo, muestran la importancia de los recursos materiales, económicos y humanos de las Bisayas, ya que el socorro ${ }^{51}$ mexicano, en más de una ocasión, también llegaba a cuentagotas. De Ilocos se obtenían jarcias, mantas y ropa de algodón; arroz de la Pampanga y Panay, y de Cebú, cerdos, ga-

de Antropología e Historia, México, Colección G. de Orozco, vol. 56, 26ª Memoria presentada a la regencia del reino por Ciriaco González Carvajal, secretario de estado y del despacho de la gobernación de ultramar, Madrid, 30 de septiembre de 1812, Fondo Reservado de la Biblioteca del Archivo Histórico del Instituto Nacional de Antropología e Historia (AHINAH).

${ }^{47}$ Orden al virrey del Perú de enviar artillería para Ternate, Manila, 8 de junio de 1608, AGI, Filipinas, legajo 329, exp. 76v. Sólo hasta 1631 se estipulaba la supresión del contacto marítimo Nueva España-Perú en un periodo de cinco años, confirmado en 1634 y otorgándole carácter de indefinido.

${ }^{48}$ Certificación sobre los servicios prestados por los agustinos de Filipinas, Manila, 15 de junio de 1640, AGI, Filipinas, legajo 76, exp. 1.

${ }^{49}$ En Filipinas se conocía corrientemente como vino a un alcohol de muy baja graduación resultado de la destilación del coco y de la nipa, un arbusto endémico en las islas. La tuba es la bebida nativa por excelencia del archipiélago; es un licor que se obtiene de la inflorescencia de la palmera, especialmente del cocotero; es el vino de la palmera de ese nombre. Manuel Buzeta, Diccionario geográfico, estadístico, histórico de las islas Filipinas, Madrid, Imprenta de Don José de la Peña, 1851, vol. I, pp. 143-144. Antonio de Morga, Sucesos de las islas Filipinas, México, Fondo de Cultura Económica, 2007, p. 295.

${ }^{50}$ Lombriz de mar.

${ }^{51} \mathrm{La}$ palabra socorro refiere la ayuda virreinal que todos los años era enviada desde el puerto de Acapulco a la capitanía general de Filipinas. Desde 1565 hasta el siglo XvIII, en términos tributarios de los folios de las cajas de Manila, se señalan los caudales novohispanos constituidos por una cantidad de plata en reales de a ocho, en pasta y labrada; un grupo de efectos y víveres demandados por la gobernación insular que subvenía a la población española intramuros Manila; y una remesa de gente de mar y guerra que en circunstancias normales llegaba a cuentagotas para los reales campos de Manila, presidios y las entradas contra los enemigos de la Corona. La plata y los caudales así como los efectos y los víveres se subdividían en otras partidas, tales como pábulos, obvenciones y estipendios destinados a la administración civil, culto religioso y actividades castrenses. 
llinas, carne de carabao y venado. Y a pesar de que Bisayas era una región recurrentemente amedrentada por las entradas malayo-mahometanas de Mindanao y Joló, se constituyeron como enclaves principales, mediante Cebú y Panay, para comunicarse regularmente con el Moluco.

Otro quebradero de cabeza igualmente complicado para la defensa del Moluco era la remesa anual de soldados, patente en la escasez de cuerdas de infantería española y novohispana en Manila. ${ }^{52} \mathrm{La}$ consecuencia inmediata fue valerse de los recursos humanos de la tierra filipina, los indígenas pampangos, "que acá son como los valones o alemanes de Flandes". ${ }^{53} \mathrm{~A}$ partir de entonces se desempeñaron como soldados, gastadores, arcabuceros, mosqueteros y en diferentes oficios en el campo de guerra, ${ }^{54}$ pues desde 1605 los cuerpos castrenses de origen español y novohispano preferían militar en las filas holandesas "porque su alteza no les pagaba". ${ }^{55}$ Se interpretaba la obediencia y fidelidad de los pampangos en beneficio de la Corona. ${ }^{56}$ Por ello, Sebastián Hurtado de Corcuera (1635-1644) decidió remudar, trianualmente, las compañías de infantería mediante un descanso en Manila, sustituyéndolas por otro contingente para evitar la deserción porque era bien conocido que "sólo los favorecidos salen de aquel presidio". ${ }^{57}$

${ }^{52}$ Carta de Felipe II sobre tropas a Filipinas, BNM, Sala Cervantes, Madrid, 2 de febrero de 1576, núm. 19629, fol. 139. Listas de gente de mar y guerra que fueron a Filipinas en los años 1618, 1625, 1633 y 1667, AGNM, AHH, México, 12 de enero de 1667, legajos 1238 y 1245 , exp. 1-3.

${ }^{53}$ Carta del gobernador Sebastián Hurtado de Corcuera a su majestad donde solicita mercenarios europeos dada la escasez para asegurar el dominio de las islas, Manila, 25 de junio de 1638, AGI, Filipinas, legajo 8, exp. 1.

${ }^{54}$ Memorial al rey del padre Juan de Tapia a su majestad pidiendo que los cuatro religiosos que asisten el convento de San Agustín de Ternate se les dé el estipendio que se acostumbra a dar a los ministros religiosos de Filipinas, Manila, 19 de noviembre de 1622, AGI, Filipinas, legajo 8, exp. 21.

${ }^{55}$ Carta de Pedro Bravo de Acuña sobre el Moluco y los holandeses, 16 de agosto de 1605, AGI, Filipinas, legajo 7, exp. 25.

${ }^{56}$ José Eugenio Borao Mateo, "Contextualizing the pampangos (and Gagayano) soldiers in the spanish fortress in Taiwan", Anuario de Estudios Americanos, vol. 70, núm. 2, julio-diciembre de 2013, pp. 585-591. Ostwald Sales-Colín, "La escasez de soldados en las Filipinas de la primera mitad del siglo xvII”, en A. Gutiérrez (coord.), Estudios sobre América, siglos XVI-XX, Sevilla, Asociación Española de Americanistas, 2005, p. 777.

${ }^{57}$ Orden de infantería para el presidio de Ternate, 5 de agosto de 1635, AGI, Filipinas, legajo 330, exp. 7v. 
Así, entre parabienes y regocijos, el socorro del Moluco se esperaba en Ternate. Aunque, a mi juicio, aún no es posible cuantificarlo por la fragmentación de las fuentes que he consultado. Por ejemplo, para agosto de 1623 se enviaron 164680 pesos, mientras en 1636 se registra un total de 92000,42000 en dinero y más de 50000 en géneros y pertrechos militares. Uno de los primeros socorros en llegar, en 1605, fue de 40000 ; luego, en 1608, ascendió a "cincuenta y cuatro mil setecientos y ochenta y tres pesos en bastimentos, vestidos, medicinas y otras cosas tocantes a mantenimiento". ${ }^{58}$

Lo que subyace bajo la retórica en cuanto al interés por Ternate también tiene otras explicaciones. Los agustinos calzados mostraban recurrentemente su apoyo material y humano al gobernador para remisionar el socorro del Moluco, quienes no destacaron precisamente por su altruismo; por ejemplo, en 1621, Alonso Fajardo informaba sobre las numerosas encomiendas vacantes en Filipinas; de inmediato, los religiosos demandaban una como prebenda por los servicios prestados a su majestad en Ternate. ${ }^{59}$

Desde 1617, la Audiencia de Filipinas decidió la pena de muerte contra los actores intelectuales del homicidio del provincial agustino Vicente de Sepúlveda, que eran los frailes Juan de Ocadis, Pedro de Herrera, José de Vides y los diáconos Ignacio de Alcaraz, Juan de Quintana y Andrés de Encinas. Por consiguiente, Pedro de Herrera y José de Vides fueron despojados de sus hábitos religiosos y de la investidura inherente a su vida prelaticia, y se les compelió en las galeras de Ternate

${ }^{58}$ No pretendo generalizar con estos botones de muestra para toda la primera mitad del siglo XVII, sino sólo echar un primer vistazo. Carta de Pedro Bravo de Acuña sobre jornada del Moluco, Manila, 1 de junio de 1606, AGI, Audiencia de Filipinas, legajo 20, exp. 3. Carta de la audiencia de Manila a su majestad sobre acuerdos tomados en la junta de guerra para tratar el socorro de Ternate, Manila, 8 de junio de 1608, AGI, Filipinas, legajo 330, exp. 75. Certificación del costo del socorro de Ternate, Manila, 1 de agosto de 1623, AGI, Filipinas, legajo 7, exp. 69. Carta de Sebastián Hurtado de Corcuera sobre gobernadores de Ternate, Manila, 31 de mayo de 1636, AGI, Filipinas, legajo 8, exp. 30. Actualmente estoy realizando la contabilidad monetaria, material y humana enviada a Ternate, aunque con datos muy fragmentados, además de una paciente búsqueda que realizo en los Philippine National Archives, Manila, Filipinas, que espero pronto arroje resultados alentadores.

${ }^{59}$ Isacio Rodríguez, Historia de la provincia agustiniana del smo. nombre de Jesús de Filipinas, vol. XvIII, Valladolid, Ediciones Estudio Agustiniano, 1986, pp. 111 y 112. 
durante seis años, habiendo sido expulsados definitivamente de Filipinas. ${ }^{60}$

El presidio también fue usado como lugar de destierro por Sebastián Hurtado de Corcuera, quien fue uno de los gobernadores generales seducido por la lisonjería y las reverencias de sus subalternos, que al no actuar de acuerdo con ese tipo de código implícito eran condenados sin propensión al perdón cuando agraviaban públicamente su figura. En ese sentido, Luisa de Cosar, viuda del sargento mayor Francisco Suárez de Figueroa, ex gobernador de Ternate, levantó una causa criminal contra el capitán general, hacia 1636, porque había despojado a su marido del gobierno del Moluco al convertirlo en prisionero y encarcelarlo en un calabozo donde murió por malos tratos. ${ }^{61}$ Para eliminar a los prelados estorbosos también los condenaba a las galeras de Zamboanga; por ejemplo, a los franciscanos Bernardino de Ávila y Antonio del Puerto, "les quitó los hábitos, mandando rapar y aprisionar como a los demás galeotes" ${ }^{62}$ por ser acérrimos defensores de la vida, persona y trayectoria del provincial José de Santa María y, en consecuencia, contrarios a los jesuitas. ${ }^{63}$ Ternate y Zamboanga sirvieron como lugares donde los disidentes de este gobernador practicaban un ostracismo forzado manteniéndose lejos.

En ese sentido, la participación de los dominicos como cómplices de los condenados a Ternate era bien conocida en función de la ayuda prestada para que algunos de los sentenciados pudieran huir. Así lo denunciaba Hurtado de Corcuera en 1636, pues los frailes dominicos Francisco de Paula y Sebastián de Oquendo, y los agustinos recoletos Alonso de Carvajal y Alonso de Ochoa encabezaban una propaganda en contra de los jesuitas e inquietaban a otros prelados y por tal motivo fueron desterrados al Moluco. Los dominicos habían planeado

${ }^{60}$ No obstante, al parecer, la sentencia no tuvo efecto contra Pedro de Herrera, quien zarpó inmediatamente para España con objeto de protestar a favor de su inocencia ante el rey y el general de su orden; lo anterior se escribe porque, en 1624, Pedro de Herrera estaba de regreso en el archipiélago, libre de toda culpa; véase ibid., vol. XVII, 1984, pp. 361 y 362.

${ }^{61}$ Ibid., vol. xx, 1988, p. 30, nota 150.

${ }^{62}$ Ibid., p. 94 , nota 447.

${ }^{63}$ Corcuera era devoto de san Ignacio y por tanto ferviente defensor de los jesuitas. 
poner pies en polvorosa antes de ser embarcados, y lograron escabullirse mediante un pago subrepticio. ${ }^{64}$ Luego, en junio del mismo año, se sancionó a ocho años a las galeras del Moluco al cirujano Francisco García por haber malogrado un embarazo. ${ }^{65}$

Todo está imbricado con el comisariado inquisitorial de Mindanao, sufragáneo del comisariado mayor de Manila, ${ }^{66}$ y con ello los intentos de fortalecimiento español allende Filipinas en cuanto al trasvase de las instituciones ya fundadas y ensayadas en la isla de Luzón. Lo anterior se anota porque, durante noviembre de 1636, el sargento mayor Juan González de Cáceres apresó en Ternate a un grupo de efectivos militares al imputarles el "abominable delito" del pecado nefando. Los soldados fueron juzgados en el comisariado mayor de Manila que, mancomunado con el gobierno insular, resolvió ocuparlos como remeros de las galeras de Ternate para protegerla contra el enemigo holandés. ${ }^{67}$ Sobre la fundación del comisariado en Mindanao se señala:

[...] tenemos entendido que en las islas de Zamboanga, Mindanao y Joló hay necesidad de tener persona que haga oficio de comisario de este Santo Oficio, por ser partes habitadas de muchos géneros de naciones y asistidas de españoles, soldados y mercaderes en sus presidios y poblaciones y que acudan a las causas que se ofrecieren y pertenecieren tocantes a este Tribunal [de Manila]. ${ }^{68}$

El 5 de marzo de 1641 fue constituido; su jurisdicción se extendía sobre Zamboanga, Joló y Ternate.

El creciente interés español por Asia Oriental era bien conocido y no sólo se limitó al Moluco. Hacia la década de 1620 se programó la ocupación del reino de Macasar, en la isla de Matheo, y se convirtió en una empresa ambiciosa, costosa y efímera, cuyo paladín más preclaro fue Alonso Fajardo de

${ }^{64}$ Ibid., vol. xx, 1988, pp. 109-111.

${ }^{65}$ Ibid., p. 31.

${ }^{66}$ Sobre los convenientes e inconvenientes que puede tener el fundarse el Tribunal de la Santa Inquisición en las islas Filipinas, Aranjuez, 24 de abril de 1659, en AGNM, Reales Cédulas Originales, vol. 416, exp. 47, fojas 148 y 149.

${ }^{67}$ Respuesta al gobernador de Terrenate sobre asuntos de guerra, Manila, 6 de diciembre de 1636, AGI, Filipinas, legajo 330, libro 4, p. 22r.

${ }^{68}$ Comisión del Santo Tribunal de México para fundar el comisariado en Mindanao, Manila, 5 de diciembre de 1641, AGNM, Ramo Inquisición, vol. 416, exp. 8, f. 190. 
Tenza (1618-1624). Geoestratégicamente, la isla ofrecía sustanciosas posibilidades comerciales entre Ternate y Luzón mediante el corredor Filipinas-Ternate-Matheo, gracias a su curiosa geografía en forma de pulpo, con cuatro penínsulas al estilo de tentáculos.

Entre los objetivos de Alonso Fajardo de Tenza se encontraba concretar una población estable con fines religiosos, como una cruzada de reivindicación, en aras de la consecución del avance de la cristiandad hacia regiones mahometanas, al imitar un reino similar al de Manila para expandir su religión hacia el resto de la Insulindia; en lo militar estaba interesado por una base segura donde recalara la ayuda que viniera de India, para que continuara segura navegación hacia Filipinas, empleándose en las batallas libradas contra el enemigo holandés en el mar de la Banda y en Malayo, a fin de desaparecer la tradicional presencia extranjera de la región; y lo comercial se traduciría en pingües ganancias pecuniarias al acceder, sin cortapisas, al estrecho de Malaca y Pegú, lugares donde se concentraba la totalidad del comercio del sureste asiático. Así, durante los años de 1602 a 1629 se estableció la Vereenigde Oost-Indishe Compagnie en la región con una firme posición en las islas Amboine y Matheo tras rubricar tratados de amistad con príncipes locales, particularmente con el de Macasar. ${ }^{69}$ Con todo, los hispanos no se arredraron, pues durante las mismas fechas los barcos de esa compañía neerlandesa navegaban sobre el mar de la Sonda y el mar Banda, y ello les daba grandes posibilidades de establecerse en Matheo.

En ese sentido, Alonso Fajardo ejerció una amplia autonomía política en el establecimiento de presidios porque sólo informó al virrey de Nueva España, y al monarca, que de haber tenido noticia del interés por Matheo, desde antes de su llegada a Filipinas y durante los primeros años de su administración pudo haber desplazado entradas para lograr un asentamiento, y se mostró dispuesto a establecer un asiento español en la isla. Este gobernador llegó en 1618, mientras que las empresas por Macasar se iniciaron hacia 1621 y se esfumaron entre 1623-1625.

${ }^{69}$ Jean Bruhat, Historia de Indonesia, Buenos Aires, Universal Buenos Aires, 1964, p. 11. 
Durante diciembre de 1621 dispuso establecerse en Matheo, en Macasar, el reino más importante en la producción de nuez moscada; ello convertía en redituable la empresa. Desde allí, la navegación con destino a Ternate sería más segura, al evitar el contacto enemigo. La isla sería una escala para las naves encargadas de transportar desde Manila, Cebú o Panay, el socorro del Moluco. En contraste con la esterilidad de la tierra de la isla del clavero, se pregonaba su abundancia de carne y arroz como fuente regular de abastecimiento, aunque también requería remitirse una obvención anual de soldados y artillería desde Filipinas. La cristianización se completaría con la presencia de seglares y religiosos dedicados al "santo bautismo"; por ello, dispuso la ayuda de la provincia de San Gregorio, donde fueron bien recibidos por los indígenas. El objetivo consistía en domeñar y usar como mano de obra a los indígenas para construir una fortificación en un lugar aún ignorado; por lo tanto, a fin de lograr mayor convencimiento, se remitieron 1000 pesos "en dinero y en las ropas y cosas que allá más estiman" ${ }^{70} \mathrm{y}$ se iniciaron superficialmente relaciones cordiales con su datu.

Después, para agosto de 1622, se insistía en continuar con la regularidad de las comunicaciones con el Moluco; entonces se dispuso la ocupación de una isleta contigua a Matheo, recién hallada y bautizada con la advocación de Santa Margarita, privilegiada por el entorno geográfico al encontrarse en la península de Monado, considerada rica en carne y otros bastimentos. ${ }^{71}$ Un año más tarde, en agosto de 1623 , se planeaba con urgencia la necesidad de levantar una fortificación en Santa Margarita, llevando desde Luzón y Bisayas lo necesario para erigirla, con la finalidad de asegurar el socorro enviado desde Manila a Ternate, e impedir así la llegada de holandeses, ingleses, borneyes y joloés. ${ }^{72}$ Con todo, hacia 1625 se desmoronó la incesante necesidad de fundar un nuevo presidio porque los

${ }^{70} \mathrm{Carta}$ de Alonso Fajardo de Tenza sobre asuntos de gobierno, Manila, 10 de diciembre de 1621, AGI, Filipinas, legajo 7, exp. 65.

${ }^{71}$ Carta de Alonso Fajardo de Tenza sobre asuntos de gobierno, Manila, 20 de agosto de 1622, AGI, Filipinas, legajo 7, exp. 67.

${ }^{72}$ Carta Alonso Fajardo de Tenza sobre socorros que había enviado a Ternate, Manila, 17 de agosto de 1623, AGI, México, legajo 2488, exp. 6. 
holandeses habían desmantelado la fuerza de Calomata; por lo tanto, se conminó al rey de Macasar a entablar un tratado de amistad con los españoles, con la pretensión de llevar a cabo una ofensiva contra el enemigo de la Corona y continuar con el Moluco como sufragáneo de la monarquía. ${ }^{73}$ Así, entre agosto de 1625 y julio de 1626 se remozó Calomata mientras los neerlandeses realizaban entradas en la península malaya. ${ }^{74}$ Los esfuerzos españoles, fundamentalmente los monetarios, se dirigieron a Ternate; entre tanto, los flamencos se establecían en las islas del mar Banda, cercanas a Matheo.

En cuanto al interés castellano por instalarse en las riberas del mar de China, en la realidad se concretó hasta 1626 sobre la isla del Norte, ${ }^{75}$ aunque el objetivo inicial había sido la conquista de China. ${ }^{76}$ En 1573 se planeó salir de Cantón con des-

${ }^{73}$ Carta de Fernando de Silva sobre asuntos de gobierno, Manila, 10 de agosto de 1625, AGI, Filipinas, legajo 7, exp. 83.

${ }^{74}$ Carta de Fernando de Silva sobre asuntos de gobierno, 30 de julio de 1626, AGI, Filipinas, legajo 7, exp. 85.

${ }^{75}$ Desde 1597, Hernando de los Ríos Coronel manifiesta la urgente necesidad de ocupar isla Hermosa por la cercanía con la tierra firme de China, porque era lugar de paso obligado de los que viajan de ella a Filipinas así como de los originarios de Japón. Insistía en ocupar el puerto de Keilang (Keelung) y defenderlo con 300 hombres y artillería con el firme propósito de mantener seguras las islas contra una conquista japonesa; al mismo tiempo, dada su posición geoestratégica, se constituía en una escala para los champanes que llevaban mercaderías sinenses para realizar comercio con Manila, que podría cortarse definitivamente frente a la belicosidad japona al vedar el viaje al archipiélago. De acuerdo con Juan Gil, la conquista del puerto de Keilang era un "proyecto muy mimado" del gobernador Luis Pérez Dasmariñas, quien temía una invasión japonesa. Gil, Mitos y utopias del descubrimiento. 2. El Pacífico, op. cit., p. 137. Memorial que dirigió al rey, desde Manila, Hernando de los Ríos Coronel dándole cuenta de un libro que estaba componiendo sobre el uso del astrolabio y arte de navegar, y de la importancia de que en tierra firme de China se tomase un puerto y al propio tiempo en isla Hermosa, Manila, 27 de junio de 1597, Archivo del Museo Naval (AMN), Colección Fernández de Navarrete, nav. XVIII, fol. 316, dto. 58. Al respecto puede consultarse la biografía publicada sobre Hernando de los Ríos Coronel, de John Newsome Crossley, Hernando de los Ríos Coronel and the Spanish Philippines in the Golden Age, Aldershot, Ahsgate, 2011.

${ }^{76}$ En aquella época, China era considerada una potencia mundial, militar, tecnológica y cultural. Felipe II envió al padre Martín de Rada en la década de 1570 y al jesuita Alonso Sánchez en la década de 1580 para realizar escarceos y recopilar información directa sobre sus recursos y sus habitantes. Martín de Rada sugería al virrey, en 1569, la ocupación total de Filipinas como paso inicial para la conquista de China. Incluso en carta de Legazpi al monarca, fechada el mismo año, donde explicaba que las islas no eran las islas de la Especiería, asegura que la futura capital del asentamiento hispano en Asia, Manila, en la isla de Luzón, se convertiría en un base segura para llegar a la tierra firme, tal como las Antillas habían servido de cabeza de puente para 
tino a la tierra firme de Chincheo, desde donde se invertiría un año de camino rumbo a Beijing. ${ }^{77}$ Felipe II enviaría tercios españoles desde la península, que sumaran unos 6000 efectivos militares; con ellos se lograría un fácil sometimiento. ${ }^{78}$ Así entonces, el provecho de la isla desde el punto de vista económico se hacía comprensible porque los gobernadores Fernando de Silva (1625-1626) y Juan Niño de Tavora (1626-1632) estaban motivados por el establecimiento de la articulación comercial China-Formosa-Filipinas. A Formosa llegaban diferentes champanes con mercancías para cargarse en el galeón de la carrera de Nueva España; pero los neerlandeses también se habían instalado en la isla y lograban interceptar barcos chinos; además, robaban y compraban bujerías de origen sinense, con lo que desestabilizaban el comercio con Filipinas y, en consecuencia, con Acapulco, a raíz de la mínima cantidad de mercancías que, de acuerdo con los gobernadores generales, llegaban a subidos precios a Manila. $^{79}$

Los holandeses ocuparon, en 1624, Amping, hoy Tainan, ${ }^{80}$ como base permanente, y se avecindaron casi treinta y ocho años frente a los diecisiete que duró la presencia hispana en isla Hermosa. Así, la preocupación de las autoridades españolas en Filipinas se concretó en el constante menoscabo del trato de China, consecuencia del inexorable asiento holandés. El resultado fue la precavida fundación de presidios españoles para explotar los recursos naturales, ya que el provecho se circunscribía a sus

saltar al continente americano. Una segunda tentativa para encabezar la conquista de China fue encabezada por Francisco de Sande en 1576. Para precisar aún más esta cuestión, véase Álvarez, El costo del imperio asiático, op. cit., pp. 31-32; Manel Ollé, La invención de China. Percepciones y estrategias filipinas respecto a China durante el siglo XVI, Wiesbaden, Harrassowitz Verlag, 2000, pp. 97-130, y Manel Ollé, La empresa de China. De la Armada Invencible al galeón de Manila, Barcelona, Acantilado, 2002.

${ }^{77}$ En especial, cambió notablemente la proporción numérica de habitantes en China con un incremento durante el siglo XVI y una caída a partir de 1620; véase Pierre Chaunu, La expansión europea (siglos XII al XV), Barcelona, Labor, 1977, p. 182.

${ }^{78}$ Noticias de Filipinas y de la China escritas por Hernando Requel enviadas desde México, 11 de enero de 1574, Ags, Secretaría de Estado, legajo 155, exp. 38. Relación sobre China, Filipinas, Siam, Java y Camboya, 1 de enero de 1578, AGS, Guerra Antigua, legajo 158, exp. 85.

${ }^{79}$ James Davison, The Island of Formosa. Past and Present, Taipéi, SMC, 1988, p. 8

${ }^{80}$ Diego Chou, "Los primeros albores entre China y España a través de Filipinas", Amerística. La Ciencia del Nuevo Mundo, núm. 1, enero-junio de 1998, pp. 23-44. 
minas de oro, plata y azufre ${ }^{81}$ además, el norte de la isla era abundante en sedas chinas llevadas fraudulentamente por los japoneses. El comercio exterior con China continental estaría asegurado por las mercancías que llegaban más baratas que las originarias de Macao; ${ }^{82}$ no obstante, las fortificaciones holandesas en Formosa e islas Pescadores impedían la presencia de los champanes en Manila porque el objetivo de los neerlandeses consistía en desmoronar el comercio sino-filipino. Entonces, el centro de los esfuerzos para ocupar la isla del Norte se justificaron el 25 de julio de 1626, tornándose en una empresa acertada porque los holandeses verían coartadas sus posibilidades de trajinar la seda de China a Europa y Japón. ${ }^{83}$ Los asentamientos españoles se fundaron en Santiago, hoy Samtiam o San Dia Jiau; Santísima Trinidad, Keelung y el fuerte San Salvador, hoy Sialian; todos ellos se establecieron como reacción frente a la amenaza de numerosos baluartes holandeses que contaban con plataformas de gruesos cañones y aguardaban a los navíos sinenses para robar la seda. ${ }^{84}$

A juicio de Tavora, con la presencia española en Formosa se establecerían relaciones comerciales directas con China que favorecerían el tráfico anual con Acapulco. Ahora bien, en 1630, Niño de Tavora aspiraba a las chapas reales, mediante las cuales se autorizaría, jurídicamente, el libre tránsito de mercaderías China-isla Hermosa. Así pues, en noviembre del mismo año se reforzó el socorro de Formosa con las esperanzas cifradas en conseguirlas; ello facilitaría que los mercaderes chinos llegaran legalmente a Filipinas con todo tipo de géneros y mercancías. ${ }^{85}$ Tenía gran validez la intención de la apertura

${ }^{81}$ En efecto, Hernando de los Ríos Coronel adelantaba de manera entusiasmada, en 1597, que isla Hermosa era una tierra fértil en arroz, carne y pescado. Presumía que se cargaban 200 navíos de pescado a China mientras que otros bastimentos necesarios se comprarían a Japón. Memorial que dirigió al rey, desde Manila, Hernando de los Ríos Coronel..., op. cit.

${ }^{82}$ Informe de los holandeses que ya tienen puerto en isla Hermosa, impiden el comercio de los chinos con Manila, Manila, 15 de agosto de 1624, AGI, Filipinas, legajo 32, exp. 17.

${ }^{83}$ Carta del gobierno de Fernando de Silva que ocupó puerto en la isla Hermosa, Manila, 25 de junio de 1636, Agr, Filipinas, legajo 74, exp. 61.

${ }^{84}$ Carta de Fernando de Silva sobre asuntos de gobierno, Manila, 30 de junio de 1626, AGI, Filipinas, legajo 7, exp. 85.

${ }^{85}$ Carta de Juan Niño de Tavora sobre la India y conflicto con los oidores de 
comercial China-isla Hermosa-Filipinas, por lo que se organizó una expedición a China, y se le entregó un espléndido presente al emperador Ming, de más de 3000 pesos, que consistía en plata labrada y paños coloridos. Pero los sueños se desmoronaron porque cuando el emisario llegó a la corte recién había fallecido el emperador; entonces, el sucesor removió de sus puestos a la gente principal. La empresa fracasó y se planteó la cuestión incierta de la distribución de mercancías chinas de Formosa a Filipinas. ${ }^{86}$

A pesar de todo, la cristianización de la gran isla de Norte se tornó en un interés primigenio por la aparente facilidad de expandir la religión a China y Japón. En la práctica, era un importante instrumento justificador del expansionismo hispano hacia las riberas del mar de China. Los frailes Bartolomé Martínez y Jacinto Esquivel comenzaron a diseminar los ideales de su dios entre los nativos kaitakelán, chinos y japoneses migrantes. ${ }^{87}$ Incluso, desde el 28 de agosto de 1626, se celebró un Definitorio en Tondo y se acordó la fundación de un convento o conventos; ${ }^{88}$ el mismo año, el arzobispo de Manila escribía que era absolutamente necesario enviar ministros de la provincia del Santo Rosario para "que ahora se pueble de religiosos de esta orden, enviarles una copiosa barcada (con muchos otros) por la necesidad que esta provincia tenía por los muchos que se les han muerto". ${ }^{89}$

En efecto, en las actas del Capítulo Provincial de 1633 se habla de cuatro casas fundadas por los dominicanos, cada una con iglesia: San Luis Beltrán, en Kimauri; Nuestra Señora del Rosario, en Tanchuy; la de Todos los Santos, en San Salvador, y la de Taparri. Pero Juan Niño de Tavora era categórico en la materia cristianizadora, porque al calor de una fácil llegada religiosa, los dominicos estaban decididos a entrar en China y Japón, hecho que derivó en molestia para el gobernador, que no había sido comunicado acerca de las pretensiones de

la Real Audiencia de Manila, Manila, 27 de noviembre de 1630, AGI, Filipinas, legajo 8 , exp. 12.

${ }^{86}$ Rodríguez, Historia de la provincia agustiniana..., op. cit., vol. XIX, 1987, p. 165.

${ }^{87}$ Chou, "Los primeros albores entre China y España a través de Filipinas", op. cit., p. 27.

\footnotetext{
${ }^{88}$ Rodríguez, Historia de la provincia agustiniana..., op. cit., vol. XVII, 1984, p. 347.
}

${ }^{89}$ Ibid., vol. XVIII, 1986, p. 374. 
los prelados, interesados en tomar Formosa sólo como cabeza de puente con los intereses cifrados para sentar plaza fuera de ella. En ese sentido, explicaba que el proyecto se concretaría "hasta que isla Hermosa estuviese muy por nosotros, y muy arraigada la fe en ella y el trato de China muy comunicable con aquella isla y, aún entonces, por el natural que conozco en los chinos y por su modo de gobierno en sus reinos, tengo por sin duda que no los consentirán jamás". ${ }^{90}$

El fomento poblacional de asiento de carácter seglar puede plantearse como otro aspecto fundamental con objeto de establecer un presidio permanente y estable. Desde 1626, Fernando de Silva ordenó a Antonio Carreño fundar un pueblo con 1500 casas, que serían construidas con "maderas olorosas" de la isla; para ello, Carreño solicitó 120 piezas de hierro y 216 arrobas de azufre de Castilla para fabricar pólvora. Muy animado insistía en el provecho desprendido de la empresa; igualmente resaltaba la presencia de un avecindamiento chino cuya característica era contar con agua dulce y limpia, frutas de Castilla y perdices. ${ }^{91}$ En conjunto, se tenían dos ventajas: a) haber logrado entradas pacíficas, y $b$ ) a pesar de la fama de la esterilidad agrícola formoseña, los españoles nuevamente se apoyaron en los asentamientos chinos, que fácilmente suministrarían alimentos, pertrechos e indumentarias, y se conformarían otra vez en "los pies y manos" de los españoles en lo referente a servicios menores, como casas de comida, albañiles y tenderos.

Una situación especialmente curiosa se registró en 1629: Juan Niño de Tavora trazó un proyecto poblacional que consistía en enganchar a mujeres de vida escandalosa para enviarlas a Formosa, a fin de lograr la limpieza de gente disoluta de Manila. Fueron enviadas al Real Colegio de Santa Potenciana, con parecer del propio arzobispo de Manila, quien le dio una nómina de las personas que serían detenidas. Todo ello redundó en el endurecimiento de posiciones entre las meretrices y el gobernador de Filipinas, ya que no estaban dispuestas a ser trasladadas arbitrariamente; entonces, apelaron a la iglesia catedral,

${ }^{90}$ Carta de Juan Niño de Tavora sobre galeón de Camboya y fiestas de Manila, Manila, 12 de agosto de 1632, AGI, Filipinas, legajo 8, exp. 1, p. 2.

${ }^{91}$ Carta de Fernando de Silva sobre asuntos de gobierno, Manila, 30 de julio de 1626, AGI, Filipinas, legajo 7, exp. 1, pp. 3 y 4. 
encabezada por Miguel García Serrano, que estuvo de acuerdo en ayudarlas, al cobijo de la religión, ofreciéndoles inmunidad. García Serrano no desistió hasta la partida del bajel; en consecuencia, "se quedaron ellas riendo de la justicia y las demás de su oficio sin el castigo ejemplar que habían menester". ${ }^{92} \mathrm{La}$ observación, en forma de queja, por el gobernador contra el arzobispo era muy conveniente; sin embargo, era una solución tomada con reservas: se contaminaría a la naciente cristiandad $\mathrm{y}$, desde el tenor religioso, basado en la moralidad y los buenos principios, necesitaba de acciones más ejemplares que desafortunadamente no brindaba Juan Niño de Tavora. De ahí su estrategia alternativa de 1630 . Ahora consideraba la migración de mujeres "de bien" cuya característica radicaba en la consigna de reproducir una "vida ejemplar", enviándolas "para la nueva población con esperanza que haya de ser aquello de lo bueno, o mejor que por acá hay". ${ }^{93}$

Al interés de la población de asiento se añadía la necesidad de fundar un colegio y un hospital. El 2 de junio de 1633, el agustino Pedro de Arce, obispo de Cebú y gobernador eclesiástico del arzobispado de Manila, aprobó la petición presentada por los Hermanos de la Mesa de la Misericordia de la ciudad de San Salvador para fundar un colegio para niños chinos y japoneses, previsto también para coreanos. El objetivo era concentrarlos, recogerlos y criarlos con las "santas costumbres" religiosas instruyéndolos en los evangelios; su formación consistiría en aprender a leer, escribir y hablar español y latín, versarse en teología y cantar, para prepararse como futuros predicadores cristianos para sus reinos. Los prelados responsables de dicha empresa serían los dominicos y los franciscanos, aunque para la misma fecha éstos se reservaban el derecho de señalar dónde se construiría el colegio, su advocación, la capacidad de la capilla, casa, aposentos, cuartos y oficinas, reparos, sustento, vestido, estipendios, médicos, medicinas, y el número y calidades de los colegiales así como de los frailes que asistirían la enseñanza de los niños. Se adelantaron 2000 pesos para la edificación y,

\footnotetext{
p. 145 .

${ }^{93}$ Carta de Juan Niño de Tavora sobre comercio con Oriente, Manila, 4 de julio de 1630, AGI, Filipinas, legajo 8, exp. 1, p. 5.
}

${ }^{92}$ Rodríguez, Historia de la provincia agustiniana..., op. cit., vol. XVIII, 1986, 
al mismo tiempo, se barajó la posibilidad de fundar un hospital contiguo al colegio para el que se aportaron otros 2000 para iniciar su construcción. ${ }^{94}$

La relevancia del establecimiento español en isla Hermosa se justificó por la incesante necesidad de fundar un reino similar al que se había creado en Manila, con algunas de las instituciones más importantes que ya se habían ensayado e inaugurado. Los límites tradicionales del área de influencia española en poniente se ampliaron, y se fortaleció el poder dentro de la conveniencia de que todas las ideas rectoras, planes, programas, proyectos y expediciones, tenían como punto neurálgico la capital del archipiélago, Manila.

\section{La imagen de la élite gobernante}

Las apreciaciones que aquí se explican no estuvieron libres de implicaciones, tales como discrepancias, contradicciones, rivalidades o rencillas personales, que quebrantaron todas las reglas de la política, de la justicia y de la prudencia. Así, pese a la visión negativa que parte de la élite gobernante tenía sobre los territorios allende Filipinas, existía también la idea compartida de que estaban frente a un potencial de riqueza natural y humana que podría ser aprovechado para el mejoramiento de poniente, aunque había voces implacables de protesta frente a esa expansión en Insulindia y las riberas de mar de China.

Desde 1605, Pedro Bravo de Acuña señalaba con resquemor que los holandeses establecerían factorías en Ternate, Tidore, Banda y Amboine similares a las que habían fundado en Patán y la Sonda. ${ }^{95}$ Tres años más tarde, en 1608, Rodrigo de Vivero escribió al rey que el objetivo fundamental de la presencia española en Asia radicaba en fortalecer el poder hispano. En su opinión, el buen gobierno de Filipinas consistía "en conservar más que en ganar otras provincias nuevas", ${ }^{96}$ porque era mínimo

${ }^{94}$ Rodríguez, Historia de la provincia agustiniana..., op. cit., vol. xvIII, 1986, p. 340.

${ }^{95}$ Carta de Pedro Bravo de Acuña sobre el Moluco y los holandeses, Manila, 8 de julio de 1605, AGI, Filipinas, legajo 7, exp. 25.

${ }^{96}$ Carta de Rodrigo de Vivero sobre asuntos de gobierno, Manila, 25 de agosto de 1608, AGI, Filipinas, legajo 7, exp. 42. 
el porcentaje de pobladores permanentes de origen peninsular y novohispano en el archipiélago y, por lo tanto, muy escasos para fundar nuevos presidios. Recomendaba conservar los territorios ganados mediante la población de asiento ya concretada. A ello se añadía la tardanza, escasez o inexistencia de la llegada de naos originarias de Acapulco, y por ello se mostraba abiertamente contrario a prolongar la presencia hispana en Ternate, sobre todo frente a los avatares para enviar el socorro del Moluco.

Ana María Prieto Lucena señala que Sabiniano Manrique de Lara (1653-1663) afirmaba que Ternate sólo originaba cuantiosos gastos a la Real Hacienda filipina. ${ }^{97}$ Entonces, ¿por qué conservarla? Una de las razones, sin pretender que sea la única ni la más importante, era el interés centrado en la explotación del clavero; además, la isla contaba con árboles de sagú, ${ }^{98}$ cuyas hojas eran empleadas para fabricar el embalaje con que se exportaba esa especia; asimismo, tenía una función significativa y primordial al ser considerada entre los pobladores molucos como la cesta del pan. Se mostraba especial importancia por Ternate, desatendida frente al escandaloso acecho holandés. Se precisaba la regularidad, puntualidad y abundancia de los despachos remisionados de Nueva España. Tres razones explicaban la importancia de los envíos: ${ }^{99}$

a) Con el situado habría éxito en la tarea cristianizadora con grandes conversiones.

b) La expansión sobre el archipiélago de Molucas sería inexorable porque el avance español dependía de los pertrechos militares enviados desde Acapulco, y robustecería la reputación de las armas españolas.

c) El establecimiento del poder en lugares lejanos de la metrópoli se reflejaría en el esfuerzo por desmoronar la presencia extranjera desalojándola de la Especiería y convirtiendo el

${ }^{97}$ Ana María Prieto Lucena, Filipinas durante el gobierno de Manrique de Lara, 1653-1663, Sevilla, Escuela de Estudios Hispanoamericanos, 1984, pp. 102 y 134.

${ }^{98}$ Con la fécula del sagú se hace una tortilla que recuerda el sabor del trigo pero más ácido; es parte de la dieta que incluso aún hoy se consume en lugares como Papúa. Cada árbol produce unos 350 kilos.

${ }^{99}$ Estado social, político y religioso de Filipinas, Manila, 7 de agosto de 1618, AGI, Audiencia de México, legajo 2488, exp. 7. 
comercio del clavo en uno de los negocios más redituables; de lo contrario, se empañaría la buena imagen del asentamiento hispano en Asia.

Pero, sobre el aprovechamiento del clavo, tanto los gobernadores de Filipinas como las autoridades españolas avecindadas en Ternate solían perderse en sueños pueriles, pues escribían mensajes y promovían estrategias en provecho propio y no de España. ${ }^{100}$ Así sucedió en 1623 cuando Alonso Fajardo de Tenza comunicó al monarca que el clavo reunido en la cosecha de Ternate se enviaba a India, y con las ganancias obtenidas se adquirían esclavos para ser empleados como remeros de las galeras de la isla y comprar bastimentos para la manutención de los soldados, aunque paradójicamente los pertrechos navales y militares eran más baratos que los originarios de Nueva España. ${ }^{101}$

También Juan Niño de Tavora insistía en exportar la especia a India. Afirmaba sobre el almacenamiento anual de $45 \mathrm{ba}$ bares $^{102}$ de clavo cuya cosecha aumentaría hasta 50 , de lo que se beneficiaría ampliamente la hacienda filipina porque el clavo alcanzaría un precio de 4000 pesos; así se obtendrían mayores ganancias al trasladar los bahares a Manila en las embarcaciones del socorro de Ternate. En la capital española el clavero incrementaría su precio a 10000 ; por consiguiente, al fletarlo con dirección a India valdría, en Goa o Cochin, 35000 , y todo ello reportaría un margen de ganancia que paliaría la escasez del socorro novohispano. Además, de acuerdo con este gobernador, mediante la contratación del clavero entre Manila e India se compraría salitre, hierro, anclas, esclavos para las galeras, armas, bizcocho, cajas, ropas blancas y ropas de vestir, que se adquirirían con los mercaderes indios que contrataban en Manila.

Pero el gobierno de Sebastián Hurtado de Corcuera respondía a la necesidad de comprender que se dilapidaba la hacienda en la cosecha del clavo, lo que incrementaba la imagen negativa

\footnotetext{
${ }^{100}$ Petición de informe sobre el clavo de Ternate, Manila, 17 de noviembre de 1607, AGI, Filipinas, legajo 329, exp. 76v-77r.

${ }^{101}$ Estado de las islas Filipinas y socorros enviados a Ternate, Manila, 17 de agosto de 1623, AGI, México, legajo 2488, exp. 5.

${ }^{102} \mathrm{El}$ bahar equivalía a unos 140 kilos.
} 
sobre el presidio del Moluco. ${ }^{103}$ Gradualmente, los negocios de Ternate fueron creando desazón, y gran desconfianza, porque los gastos eran exageradamente cuantiosos y el provecho inexistente, lo que denostaba aquella fuerza. Durante esta primera mitad del siglo XVII se produjeron varios escritos, comentarios, pareceres, decretos, ordenanzas y cédulas reales relacionadas con la producción del clavo en las Molucas; incluso se tocaba el rendimiento, transportación y negociación a través de India. Los de algunos vecinos-mercaderes involucrados en este negocio resumían con gran entusiasmo el proyecto, que sería un maná de posibilidades económicas. No obstante, los comentarios del Consejo de Indias eran contrarios, pues los beneficiarios de este tráfico solamente eran los gobernadores de Filipinas y Ternate, además de los inversionistas avecindados en Manila.

Esta cuestión parece seguir siendo el ámbito genuino de la pesadumbre respecto a la lamentable problemática desprendida de la posesión del Moluco. ${ }^{104}$ Como ejemplo puede servir que en vísperas del estridente descalabro en las comunicaciones Acapulco-Manila, de 1646 a 1648, la East India Company presentó un proyecto a Felipe IV mediante el cual se practicaría el intercambio comercial con Molucas, lo que hincharía de plata las cajas insulares, que tendrían una ganancia de 500000 pesos de a ocho. Con ello, los ingleses demandaban el libre tránsito de mercaderías entre Manila, Molucas y sus factorías indonesias. ${ }^{105}$ Todo lo anterior permite esbozar la hipótesis basada en la polémica temprana de libre comercio entre la East India Company y Filipinas, porque los ingleses abogaban por la exención del pago de almojarifazgo al atracar en los puertos de la monarquía. Entonces, en el Moluco sería entregada la pimienta ${ }^{106}$ a los navíos de la East India Company, que seguirían el derrotero

${ }^{103}$ Carta de Sebastián Hurtado de Corcuera sobre el mal estado de la Real Hacienda filipina, Manila, 26 de junio de 136, AGI, Filipinas, legajo 8, exp. 60.

${ }^{104}$ Carta de Juan Niño de Tavora sobre materias de hacienda, Manila, 1 de agosto de 1629, AGI, Filipinas, legajo 8, exp. 7.

${ }^{105}$ Proposición de la Compañía Inglesa de la Indias Orientales de realizar comercio con Manila y Ternate, Madrid, 27 de agosto de 1646, AGs, Secretaría de Estado, legajo 865 , exp. 1.

${ }^{106}$ A pesar de que en la documentación no se indica el origen de la pimienta, en el siglo Xvil el comercio de Filipinas con Borneo fue en gran escala y con volúmenes muy importantes, pues entre sus producciones más sobresalientes estaban: cobre, diamantes, alcanfor, cera y pimienta. 
Ternate-Cabo de Buena Esperanza-España transportándola, sin pagar derechos, hasta la bahía de Cádiz o al puerto de San Lúcar de Barrameda. ${ }^{107}$

La mejor parte se la llevaría la East India Company, muy interesada en la venta de diferentes mercaderías que escaseaban en Filipinas, tales como salitre, arcabuces, mosquetes, espadas, balas, pólvora y hierro, debido a los mínimos porcentajes enviados desde el virreinato mexicano. Por ello, el 14 de agosto de 1646, el proyecto de la East India Company fue discutido en el Consejo de Indias. ¿Qué efecto causó? La respuesta fue lacónica y estentórea porque al comercio de Filipinas "siempre se ha procurado tenerle libre de extranjeros". ${ }^{108}$ Se revocaron todas las licencias y se restituyó el dinero adelantado para el concierto. Los argumentos del Consejo fueron los siguientes:

a) Evitar la presencia de extranjeros en Filipinas y Sevilla porque las islas, al encontrarse remotas de la metrópoli, eran codiciadas por los neerlandeses, que, además de mantener la incesante guerra contra los españoles en las aguas del mar de Filipinas, ya se habían apoderado de isla Hermosa desde 1642. La inconveniencia de la contratación se apoyaba en la introducción del comercio de la East India Company en el sureste de Asia con exclusión de los españoles. ${ }^{109}$ Este punto de vista parece haber pasado a un primer plano porque el trato comercial entre ingleses y holandeses avecindados en Molucas era una vulgar añagaza, al considerar que la East India Company y la Vereenigde Oost-Indishe Compagnie estaban coligadas a fin de apoderarse de las islas de poniente.

b) El asiento de la pimienta en manos de los ingleses ocasionaría fuertes pérdidas económicas a las cajas filipinas, pues el valor de la especia estaría sujeto al establecido por la East India Company, en menoscabo de la presencia hispana.

c) La conquista de Manila por los ingleses convertía al último mundo $o^{110}$ en un territorio que "se hallaría flaco parala defensa".

${ }^{107}$ Proposición de la Compañía Inglesa de la Indias Orientales de realizar comercio con Manila y Ternate, doc. cit.

${ }^{108}$ Idem.

${ }^{109}$ Idem.

${ }^{110}$ Los gobernadores generales de Filipinas aluden peyorativamente al archipiélago denostándolo como fin del mundo o último mundo. 
El porcentaje de familias españolas avecindadas en poniente era minúsculo, aunque no es casual que se afirmara que en pocos años "serían los habitantes en más crecido número con respecto a los naturales”, ${ }^{111}$ si bien el riesgo más delicado era la reputación de las armas españolas en Asia, al crearse una visión contraria frente al Moluco respecto a la ininterrumpida sujeción de Filipinas, sufragánea de la Corona.

Pero en la ideología irredentista de los gobernadores de Filipinas existía una apreciación favorable hacia la isla de Matheo. Juan Cerezo de Salamanca (1633-1635) pactó treguas amistosas con el régulo de Macasar. Una de ellas en 1633; ese año recibió cartas del datu que le informaban sobre la llegada de catorce urcas flamencas que solicitaban refresco para la tripulación. Con la presencia del enemigo, el gobernador desistió de establecer contacto con los marineros que viajaban de India con destino a Manila. La otra, cuando en 1634 los indígenas botunes repelieron la presencia neerlandesa al asesinar a la tripulación de las embarcaciones cercanas al mar Banda, mar de la Sonda e islas de la Especiería, por lo que se tornó en un aliciente la fácil entrada del socorro del Moluco en Calomata. ${ }^{112}$

Diego Fajardo y Chacón (1644-1653) igualmente se mostraba partidario de esos vínculos porque, durante 1647, los portugueses vendieron por órdenes del rey de Macasar, a los representantes del gobierno español, bastimentos y pertrechos militares y navales enviados a la plaza de Manila. Durante 1649 nuevamente llegaron a Luzón algunas correspondencias de Matheo. El rey de Macasar envió diferentes géneros junto con una embajada a Manila, que llevó una carta para la Real Audiencia con noticias que anunciaban las pretensiones de los lusitanos, muy decididos en llegar a Filipinas; al mismo tiempo, el archipiélago se encontraba en estado de descrédito por la inexistencia de municiones para combatir y repeler a los enemigos europeos. ${ }^{113} \mathrm{La}$ importancia de la ayuda macasarí también fue muy valorada por

\footnotetext{
${ }^{111}$ Proposición de la Compañía Inglesa de la Indias Orientales de realizar comercio con Manila y Ternate, doc. cit.

${ }^{112}$ Carta de Juan Cerezo de Salamanca sobre materias de guerra, Manila, 10 de agosto de 1634, AGI, Filipinas, legajo 8, exp. 26.

${ }^{113}$ Orden sobre comercio de portugueses en Manila, Manila, 10 de diciembre de 1652, AGI, Filipinas, legajo 330, exp. 10r.
} 
Sabiniano Manrique de Lara (1653-1663). Pero hubo otros factores, los arraigados tratos y contratos que los mercaderes mexicanos asentados en Manila así como los que los agustinos calzados mantenían con Macasar a través de activas relaciones comerciales. ${ }^{114}$

Al presidio de isla Hermosa, el nuevo gobernador de Filipinas, Juan Cerezo de Salamanca, decidió reformarlo ${ }^{115}$ durante agosto de 1634, pues afirmaba que esa empresa expansionista era huera. El oportunismo de la presencia lusitana de Macao maltrataba los bajeles españoles arribados a aquellas costas. ${ }^{116} \mathrm{La}$ ayuda de Portugal era fundamental porque formaba parte de la Unión Ibérica; por lo tanto, se requería de la asistencia de Macao en la seguridad del socorro de Formosa, remitido desde Manila o Cavite, a Keelung, Tanshuy o San Salvador, aunque en la realidad las naves castellanas eran cañoneadas y se iban a pique; así, desde Luzón llegaban a despacharse envíos perentorios o en casos de extrema necesidad.

La comunicación Luzón-Formosa era semestral. Desde Manila se destacaban dos pataches que realizaban la travesía directa en una noche, si no tropezaban con dificultades de enemigos, arribadas y vendavales, aunque todo era en detrimento de las cajas manileñas al invertir en uno que zarpaba en abril y otro en agosto, mientras el Moluco, aún más lejano, sólo recibía uno. Se concebía como disparatado que la hacienda insular gastara más dinero en plazas cercanas y abultara el déficit del gobierno filipino.

En cuanto a la población española avecindada en Formosa estaba concentrada en Keelung, San Salvador y Tanchuy. Cada una empleaba tres compañías de infantería española, soldados pampangos, indios flecheros ${ }^{117}$ y personas del real servicio. Las raciones alimenticias superaban las 400; en ese sentido, se buscaban estrategias alternativas para disminuirlas en beneficio del

${ }^{114}$ Información hecha por el juez provisor y vicario general de este arzobispado de los tratos y contratos que los religiosos de San Agustín de las islas Filipinas tienen con los naturales de los partidos y doctrinas que administran, Manila, 4 de agosto de 1650, AGI, Filipinas 9, legajo 13, exp. 4.

${ }^{115}$ En este caso significa desaparecerlo. Memorial sobre asuntos de Filipinas, 1624-1635, Manila, 16 de julio de 1640, AHN, Nobleza, legajo 3361, exp. 6, 7 y 8.

${ }^{116}$ Carta de Juan Cerezo de Salamanca sobre justicia y guerra, Manila, 10 de agosto de 1634, AGI, Filipinas, legajo 8, exp. 23.

${ }^{117}$ Eran negritos de las islas Bisayas y Luzón. 
ahorro de la hacienda filipina. En cuanto a los efectivos militares, su número no superaba los 600 respecto a los 2000 acantonados en Luzón; con ellos no podrían chusmarse ${ }^{118}$ las embarcaciones necesarias para la defensa de la isla, con lo que se descuidaría la permanencia hispana. En efecto, isla del Norte se percibía como una tierra abundante, pero "los naturales [son] tan intratables que no dejan valernos de los frutos de ella", si se suman sus cualidades indómitas, traducidas en la matazón de españoles; ${ }^{119}$ la población sufría los ataques indígenas in situ y la escasez de alimentos.

Igualmente, los holandeses imposibilitaban una avanzada total; instalados en amplios y mejores lugares, sólo los separaban 50 leguas de los asentamientos españoles, y tampoco había caminos bien trazados y seguros por tierra; así, los puertos castellanos no competían con los flamencos, cuyas sólidas fortificaciones resguardaban un creciente número de naves. Al igual que su coetáneo Niño de Tavora, Salamanca apuntaba que lo fundamental era el establecimiento del corredor comercial China-isla Hermosa-Filipinas, que sería ventajoso para el comercio transpacífico, pero las embarcaciones chinas atracaban en Formosa para vender sus mercaderías a los lusitanos, que después trajinaban los españoles a Manila. En ese sentido, los consignatarios de los comerciantes mexicanos instalados en Formosa y los portugueses amasaban cuantiosas ganancias ya que revendían en Manila los productos que anteriormente llevaban los sangleyes; por lo tanto, el archipiélago no gozaba de ningún provecho.

Próxima a China, sólo 125 leguas, y distante de Japón a 195, el intercambio comercial Japón-Formosa-Filipinas estaba muy lejos de concretarse porque los frailes migraban ilegalmente a tierra japona. En consecuencia, se prohibió la salida de religiosos de Formosa pues "lo que más importa con Japón es el trato comercial”. Hacia 1638 los Tokugawua elevaron su política sakoku sin que la ordenanza surtiera efecto en el anhelado comercio. ${ }^{120}$

${ }^{118}$ Chusmar es una palabra que aparece en la documentación empleada y se refiere a reunir el grupo de marineros y soldados para aprestar los bajeles.

${ }^{119} \mathrm{H}$. de los Ríos Coronel apuntaba que los habitantes de isla Hermosa "eran gentes semejantes a los naturales de estas islas [Filipinas], los cuales roban y matan”. Memorial que dirigió al rey, desde Manila, Hernando de los Ríos Coronel..., op. cit.

${ }^{120}$ Hernando de los Ríos Coronel se comprometió el 29 de octubre de 1612 a buscar una derrota para el tornaviaje de Filipinas a Nueva España con la intención 
Finalmente, los dominicanos "hasta ahora no han reducido al santo bautismo a una sola persona”. La solidez de la avanzada cristiana era puesta en tela de juicio, al presentar una visión contraria a la de Juan Niño de Tavora, quien aseguraba que se habían hecho importantes conversiones religiosas.

Juan Cerezo de Salamanca porfiaba por "que la conservación de estas islas [Filipinas] consiste en no abarcar nuevas empresas sino en tener bien defendidos los presidios inexcusables reformando los de menor importancia”. ${ }^{121}$ Así, Manila contaría con gruesas compañías de infantería, lo que fortalecería la presencia española en Filipinas sin "perder nada de lo que ya está a cargo de la monarquía”. Con estas expresiones se mostraba reacio a la consecución de la isla del Norte como parte del avance español en las riberas del mar de China.

\section{Conclusión}

La intención principal de este escrito ha sido continuar con el estudio del establecimiento del poder en lugares lejanos de la metrópoli.

de que desde Manila se subiría en junio para llegar a mediados de julio a Japón; ahí se refrescaría el barco en su viaje hasta las costas americanas haciéndolo menos duro. El shogun Ieyasu había intentado establecer en vano, desde 1602, trato con Nueva España porque Japón después de experimentar el revés de la guerra de Corea, en 1597, se mostraba más pacífico para intervenir en la diplomacia y en el comercio del Mar del Sur. La solicitud que llevaba Sebastián Vizcaíno para entablar comercio con Japón manifestaba las exigencias del gobernador de Filipinas, Juan de Silva: a) expulsar a los holandeses; b) venta de mercaderías en el archipiélago japonés sin pancada, y c) vedar la salida de plata japonesa a Filipinas, aunque el shogun no estuvo de acuerdo con la prohibición de los holandeses a su reino. Gil, Mitos y utopías del descubrimiento. 2. El Pacífico, op. cit., pp. 142-146. Los españoles se interesaban por el arroz japonés, más barato que el comprado en las islas, cuyo encarecimiento se atribuye a los agustinos calzados que lo vendían a subidos precios a la Corona para alistar los matalotajes del barco en su viaje a la Nueva España. Mientras que entre los productos japoneses que se importan a Filipinas, antes de 1638 , para ser reexportados al virreinato mexicano se encuentran objetos suntuarios tales como biombos pintados con oro y arroz hechos de maderas preciosas con clavazón, escribanías forradas de cuero, calderitas de cobre para calentar agua para el té, escudillas de porcelana, espejeras peinadoras de mujer de barniz dorado y catanas. Memoria de mercancías originarias de Japón, Manila, 1600-1628, AGI, Filipinas, legajo 8, exp. 88.

${ }^{121}$ Carta de Juan Cerezo de Salamanca sobre materias de guerra, Manila, 10 de agosto de 1634, AGI, Filipinas, legajo 8, exp. 26. 
Se ha fundamentado que los programas de Pedro Bravo de Acuña, Alonso Fajardo de Tenza y Juan Niño de Tavora tenían la misma estructura: a) salir de las áreas hispano-filipinas ya sometidas; b) fundar nuevos presidios con población estable; c) explotar recursos naturales y humanos; d) cristianizar, y e) ampliar las comunicaciones entre Filipinas y las islas aledañas. Hubo otras opiniones, como las resolutorias de Rodrigo de Vivero, Sebastián Hurtado de Corcuera, Juan Cerezo de Salamanca y el Consejo de Indias, que tienen el mismo mensaje de reformar gastos superfluos para las cajas insulares, continuar con la conquista interna y no alentar la confianza de la navegación en aguas plagadas de enemigos.

En lugar de ostentar públicamente la reputación en empresas baladíes, dilapidando socorros y situados novohispanos, se requería consumar la internalización del archipiélago. Estas actitudes sugieren racionalidad, pensamiento sereno y trato justo para la Corona. No eran cuestiones de honor monárquico ni de ética gubernamental; expresaban el surgimiento de una organización basada en la moderación. En torno de ambos casos es posible sustentar la comprensión de cómo se veía el fortalecimiento en Asia, porque los gobernadores expresan una capacidad de acción individual sin cortapisas. Puede establecerse que se conformaron como un grupo social poderoso en un momento crítico de la historia de Filipinas, pues su ámbito permaneció cerrado para los virreyes novohispanos, ya que sus informes, plagados de una subjetividad excesiva, plantean irrefragablemente un amplio conocimiento de las islas del sureste asiático.

El fortalecimiento como percepción de la realidad modeló los intereses centrados en valerse de los recursos de la tierra filipina, e impuso un esquema que se colmataría en el siglo XVIII con la rentabilidad de poniente. Con bastante seguridad, el fortalecimiento allende Filipinas ofrece tres interpretaciones: se presenta como una amplia autonomía política de los gobernadores, después como un conjunto de empresas donde la ayuda novohispana era imprescindible, y finalmente como un panorama de reformas que beneficiarían a las islas. Clasifica una época de cambio del siglo XVI al XVII que fue acuñada en la historiografía con la palabra consolidación. Se asiste a un objeto de estudio 


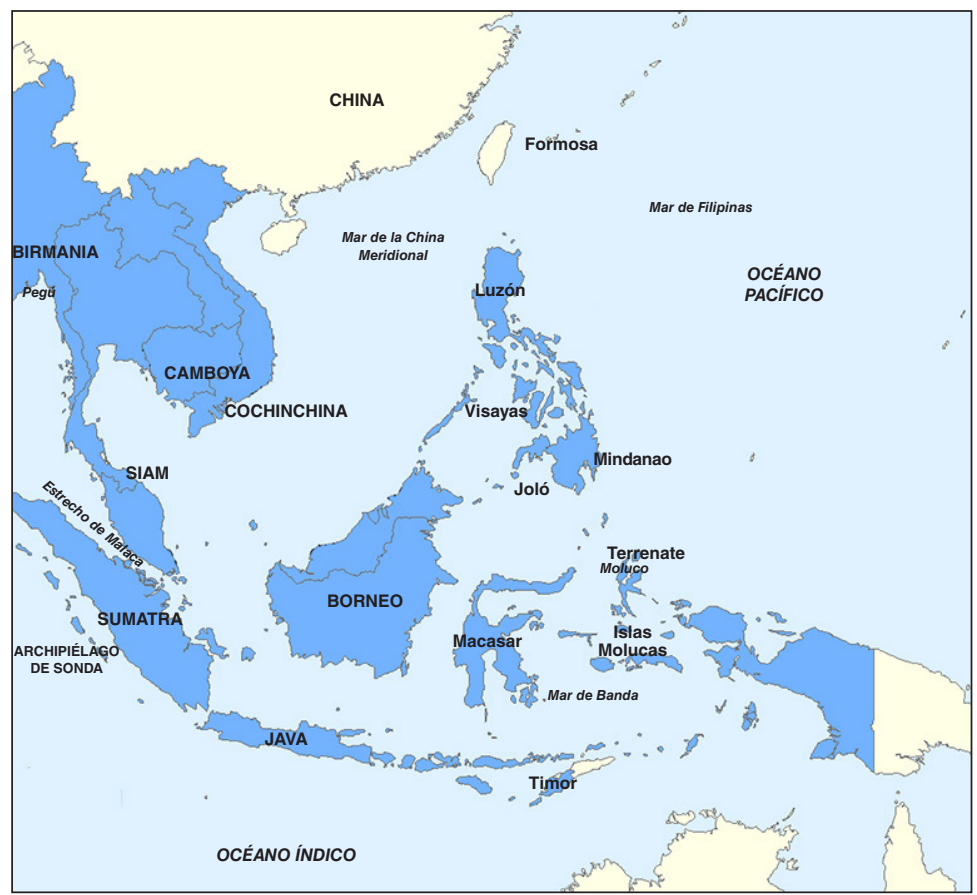

trascendental en lo que se refiere al establecimiento del poder en lugares lejanos de la metrópoli, con la Nueva España como base permanente de la relación con Filipinas, que genera un contacto en cadena mundial: Asia-América-Europa. Simboliza el poder central del último mundo, casi aislado de imposiciones e intereses confrontados en la avanzada hacia las islas del Pacífico asiático durante la primera mitad del siglo XVII.

Dirección institucional del autor:

Departamento de Sociología

Universidad Autónoma Metropolitana-Azcapotzalco

Av. San Pablo 180

col. Reynosa Tamaulipas, Azcapotzalco

02200, México D.F.

$\triangle$ sangley@hotmail.com 


\section{Bibliografía}

Aguilera Rojas, Antonio, Manila, 1571-1898. Occidente en Oriente, Madrid, Universidad de Alcalá-Instituto Español de Arquitectura-Agencia Española de Cooperación Internacional-Ministerio de Asuntos Exteriores-Ministerio de Fomento-Centro de Estudios y Experimentación de Obras Públicas-Centro de Estudios Históricos de Obras Públicas y Urbanismo, 1988.

AlONSO Álvarez, Luis, El costo del imperio asiático. La formación colonial de las islas Filipinas bajo dominio español, 1565-1800, MéxicoCoruña, Instituto Mora-Universidade da Coruña, 2009.

Alva Rodríguez, Inmaculada, "La centuria desconocida: el siglo XVII", en L. Cabrero (coord.), Historia general de Filipinas, Madrid, Ediciones de Cultura Hispánica, 2000, pp. 207-248.

Alva Rodríguez, Inmaculada, "Urbanismo municipal en Manila (siglos XVI-XVII)”, en A. García-Abásolo (coord.), España y el Pacífico, Córdoba, Universidad de Córdoba-Instituto de Cooperación Internacional, 1997, pp. 157-165.

Archivo General de Indias, Paisajes urbanos de América y Filipinas, Sevilla, Ministerio de Educación, Cultura y Deporte, 2000.

BAUZON, Leslie, "Amplia perspectiva: relaciones intercoloniales mexicano-filipinas", en E. de la Torre Villar (comp.), La expansión hispanoamericana en Asia, siglos XVI-ХVII, México, Fondo de Cultura Económica, 1980, pp. 77-85.

Borao Mateo, José Eugenio, “Contextualizing the Pampangos (and Gagayano) Soldiers in the Spanish Fortress in Taiwan”, Anuario de Estudios Americanos, vol. 70, núm. 2, julio-diciembre de 2013, pp. 581-605.

BruHAt, Jean, Historia de Indonesia, Buenos Aires, Universal Buenos Aires, 1964.

BuZETA, Manuel, Diccionario geográfico, estadístico, histórico de las islas Filipinas, Madrid, Imprenta de Don José de la Peña, 1851.

Chaunu, Pierre, La expansión europea (siglos XII al XV), Barcelona, Labor, 1977.

Chaunu, Pierre, Las Filipinas y el Pacífico de los ibéricos, siglos XVI, XVII y XVIII, México, Instituto Mexicano de Comercio Exterior, 1976.

Chou, Diego, "Los primeros albores entre China y España a través de Filipinas”, Amerística. La ciencia del Nuevo Mundo, núm. 1, enero-junio de 1988, pp. 23-44.

Crossley, John Newsome, Hernando de los Ríos Coronel and the Spanish Philippines in the Golden Age, Aldershot, Ashgate, 2011. 
Davison, James, The Island of Formosa. Past and Present, Taipéi, SMC, 1988.

Díaz-Trechuelo, María de Lourdes, "Bibliografía española sobre Filipinas en el siglo xx”, en F. Solano, F. Rodao y L. E. Togores (eds.), Extremo oriente ibérico. Investigaciones históricas: metodología y estado de la cuestión, Madrid, Agencia de Cooperación Internacional-Consejo Superior de Investigaciones Científicas, 1989, pp. 343-382.

Díaz-Trechuelo, María de Lourdes, "Las Filipinas, en su aislamiento, bajo el continuo acoso", en Historia general de España y América. América en el siglo XVII. Evolución de los reinos hispánicos, tomo IX-2, Madrid, Rialp, 1984, pp. 129-152.

DíAz-TRechuelo, María de Lourdes, Arquitectura española en Filipinas, 1565-1800, Sevilla, Escuela de Estudios Hispanoamericanos, 1959. García, María, "El comercio Acapulco-Manila: un intento de estado de la cuestión", en C. Yuste (coord.), Comercio marítimo colonial. Nuevas interpretaciones y últimas fuentes, México, Instituto Nacional de Antropología e Historia, 1997, pp. 165-180.

García, María, "La batalla de la seda", en A. Tortolero (coord.), Estudios históricos, México, Universidad Autónoma Metropolitana, 1993, pp. 39-67.

GARCíA-ABÁsolo, Antonio, "Formación de las Indias orientales españolas. Filipinas en el siglo XvI", en L. Cabrero (coord.), Historia general de Filipinas, Madrid, Ediciones de Cultura Hispánica, 2000, pp. 169-205.

GarcíA-ABÁSOlo, Antonio, "Investigaciones sobre Filipinas en Andalucía”, Revista de Indias, vol. XLIX, núm. 187, 1989, pp. 767-778.

García-AbÁsolo, Antonio, "La expansión mexicana hacia el Pacífico: la primera colonización de Filipinas. 1570-1580", Historia Mexicana, vol. XXXII (1), núm. 125, julio-septiembre de 1982, pp. 55-88.

García Picazo, Paloma, ¿Qué es esa cosa llamada "relaciones internacionales"? Tres lecciones de autodeterminación y algunas consideraciones indeterministas, Madrid-Barcelona, Marcial Pons, 2000.

GIL, Juan, Mitos y utopías del descubrimiento. 2. El Pacífico, Madrid, Alianza Universidad, 1989.

GonzÁlez Pola, Manuel, "Dominicos en extremo oriente. Bibliografía general sobre su actividad misionera”, en F. Solano, F. Rodao y L. E. Togores (eds.), El extremo oriente ibérico. Investigaciones históricas: metodología y estado de la cuestión, Madrid, Agencia Española de Cooperación Internacional-Consejo Superior de Investigaciones Científicas, 1989, pp. 277-295. 
Gutiérrez, Lucio, Historia de la Iglesia en Filipinas. 1565-1900, Madrid, Mapfre, 1992.

HinRICHS, Ernst, Introducción a la bistoria de la edad moderna, Madrid, Akal, 2001.

Molina, Antonio, Historia general de Filipinas, Madrid, Ediciones de Cultura Hispánica-Instituto de Cooperación Iberoamericana, 1984, vol. 2.

Morga, Antonio de, Sucesos de las islas Filipinas, México, Fondo de Cultura Económica, 2007.

Ollé, Manel, La empresa de China. De la Armada Invencible al galeón de Manila, Barcelona, Acantilado, 2002.

Ollé, Manel, La invención de China. Percepciones y estrategias filipinas respecto a China durante el siglo XVI, Wiesbadenm, Harrassowitz Verlag, 2000.

PARKer, Geoffrey, España y la rebelión de Flandes, Madrid, Nerea, 1989.

PARKer, Geoffrey, La guerra de los Treinta Años, Barcelona, Crítica, 1988.

Pérez Herrero, Pedro, América Latina y el colonialismo europeo (siglos XV-XVIII), Madrid, Síntesis, 1992.

Pérez Herrero, Pedro, Comercio y mercados en América latina colonial, Madrid, Mapfre, 1992.

Pérez Herrero, Pedro, Plata y libranzas. La articulación económica del México borbónico, México, El Colegio de México, 1988.

Prieto Lucena, Ana María, Filipinas durante el gobierno de Manrique de Lara, 1653-16, Sevilla, Escuela de Estudios Hispanoamericanos, 1984.

Prieto Lucena, Ana María, "El Pacífico en las revistas del CSIC", Revista de Indias, vol. XLIX, núm. 187, 1989, pp. 829-844.

Rodao, Florentino, Españoles en Siam (1540-1939). Una aportación al estudio de la presencia hispana en Asia, Madrid, Consejo Superior de Investigaciones Científicas, 1997.

RODRíGUEZ, Isacio, Historia de la provincia agustiniana del smo. nombre de Jesús de Filipinas, Valladolid, Ediciones Estudio Agustiniano, 1984, 1986-1988, vols. XVII-XX.

Romano, Ruggero, Coyunturas opuestas: la crisis del siglo XVII en Europa e Hispanoamérica, México, El Colegio de México-Fondo de Cultura Económica, 1993.

SAles-Colín, Ostwald, "El movimiento portuario de Acapulco: un intento de aproximación (1626-1654)”, Revista Complutense de Historia de América, núm. 22, 1996, pp. 97-119.

Sales-Colín, Ostwald, "La escasez de soldados en las Filipinas de la 
primera mitad del siglo XvII", en A. Gutiérrez (coord.), Estudios sobre América, siglos XVI-XX, Sevilla, Asociación Española de Americanistas, 2005, pp. 775-794.

Sales-Colín, Ostwald, "Las cargazones del galeón de la carrera de poniente: primera mitad del siglo XVII", Revista de Historia Económica, año XVIII, núm. 3, otoño-invierno de 2000, pp. 629-669.

TORMO SANZ, Leandro, "Bibliografía sobre la historia de la Iglesia en el extremo oriente relacionada con España", en F. Solano, F. Rodao y L. E. Togores (eds.), Extremo oriente ibérico. Investigaciones históricas: metodología y estado de la cuestión, Madrid, Agencia de Cooperación Internacional-Consejo Superior de Investigaciones Científicas, 1989, pp. 391-413.

Yuste LóPez, Carmen, El comercio de la Nueva España con Filipinas, 1590-1785, México, Instituto Nacional de Antropología e Historia, 1984.

Yuste López, Carmen, Emporios transpacíficos. Comerciantes mexicanos en Manila, 1710-1815, México, Instituto de Investigaciones Históricas de la Universidad Nacional Autónoma de México, 2007. 